\title{
O fim do romance em Memórias Póstumas de Brás Cubas
}

\section{The end of romance in Memórias Póstumas de Brás Cubas}

\author{
Victor Hermann Mendes Pena \\ Universidade Federal de Minas Gerais, Belo Horizonte
}

Resumo: O objetivo do presente artigo é analisar certos aspectos estruturais da obra Memórias Póstumas de Brás Cubas e cotejá-los em conexão ao romance enquanto gênero literário. Para tal, utiliza como referência, para além da fortuna crítica do autor, o filósofo Walter Benjamin e sua análise da relação entre o narrador e o romancista. A hipótese consiste em apontar que a obra de Machado de Assis inverte aspectos cruciais do gênero romanesco - notadamente, a função do fim do romance e sua correspondência com a musa da reminiscência.

Palavras-Chave: romance; reminiscência; Walter Benjamin; Machado de Assis

\begin{abstract}
The aim of this academic paper is to analyse some structural aspects of the work Memórias Póstumas de Brás Cubas regarding to the notion of romance as a literary gender. It uses as reference some critics of the author and also the work of the philosopher Walter Benjamin about the relationship between the narrator and the novelist. The hypothesis will indicate that the work of Machado de Assis inverts some crucial aspects of the romance gender - particularly, the function of the end of romance and its correspondence with the muse of reminiscence.
\end{abstract}

Keywords: romance; reminiscence; Walter Benjamin; Machado de Assis

\section{Introdução}

No presente ensaio serão estudados alguns aspectos da obra Memórias Póstumas de Brás Cubas, entre eles: a importância do livro e do papel como suporte da palavra escrita; a ênfase em garatujas e rabiscos "sem intenções tipográficas"; a relação desses pedaços de papel com a reminiscência e com as sensações; o objeto livro como "único

eISSN: $2179-8478$

DOI: $10.17851 / 2179-8478.11 .123-176$ 
exemplar" das memórias; a ação do verme como roedor do livro e das reminiscências; a relação do verme com a história do gênero romanesco; a relação da reminiscência com a vida e com a noção de valor; por fim, alguns limites e convenções do gênero romanesco, segundo a ótica do narrador das Memórias.

Esses aspectos da obra visam, em conjunto, sustentar a hipótese deste ensaio: a de que Memórias Póstumas de Brás Cubas fora escrito como um sistema romanesco fechado em si próprio e que tal "contração cadavérica" teria por função última carcomer os principais efeitos do romance enquanto gênero literário consagrado. Para sustentar esta hipótese, retomaremos a discussão de Walter Benjamin acerca da importância da morte e do fim do livro para a articulação da "musa do romance", a reminiscência. Nossa hipótese é a de que Machado de Assis, ao ter buscado compor um romance póstumo sem qualquer relação positiva com a vida e/ou o sentido que emanaria sob perspectiva reminiscente, teria transtornado a relação típica do romance com a musa da reminiscência.

\section{Caprichos despóticos}

É conhecida a pergunta de Capistrano de Abreu, quando do lançamento do livro: “As Memórias Póstumas de Brás Cubas são um romance?” (ASSIS, 2008, p.1). Bastou a Machado repetir-lhe as palavras de Brás Cubas que, presciente, respondia logo no prólogo que sim e que não:

Acresce que a gente grave achará no livro umas aparências de puro romance, ao passo que a gente frívola não achará nele o seu romance usual; ei-lo aí fica privado da estima dos graves e do amor dos frívolos, que são as duas colunas máximas da opinião. (p.2).

eISSN: $2179-8478$

DOI: $10.17851 / 2179-8478.11 .123-176$ 
Porém, essa pergunta continua, de algum modo, a repercutir em toda a fortuna crítica da obra. Décio Pignatari, no capítulo "Rabisco Sem Intenção Alfabética", do livro Semiótica e Literatura (2004), ecoa a persistência:

O crítico Barreto Filho, sem deixar de render-lhe o culto emblemático de praxe e que representa o paradigma da média da crítica machadiana - refere-se a essa obra em termos como "livro esquisito", "arbitrário", "narrado antes do que vivido", "a ação perde muito de importância, em favor do comentário marginal", "abuso de artifícios", "desordem da construção", "excentricidade de alguns temas", "por momentos antipáticos e de mau gosto", "disforme".

É isso aí, é com isso que se pretende guindar - eu disse, guindar - a literatura brasileira - note-se bem, brasileira - a níveis internacionais. (PIGNATARI, 2004, p.133)

Conforme nota Pignatari, a crítica machadiana em geral, se admite o livro como um grande romance, não o faz sem ressalvas. E estas comumente se resolvem distinguindo o narrador do autor, Brás Cubas de Machado de Assis, atribuindo o verdadeiro significado do romance àquilo que o autor teria deixado entrever nas linhas daquele narrador. Desse modo, esperam reconciliar a estima dos graves e dos frívolos: os eventuais desajustes aparentes do romance deverão sempre ser ressignificados tendo em vista uma eventual intenção oculta. Entretanto, Machado de Assis, ele próprio, já fizera uma prevenção acerca desse procedimento quando, ao comentar sua obra, disse: "Não digo mais para não entrar na crítica de um defunto, que se pintou a si e a outros, conforme lhe pareceu melhor e mais certo." (ASSIS, 2008, p.2).

José Veríssimo, em História da Literatura Brasileira, de 1915, apontava para o que de concreto deve-se buscar no romance, o realismo para além do artifício vulgar da narrativa:

Ainda em algum tipo, episódio, ou cena de pura fantasia, nunca a ficção de Machado de Assis afronta o nosso senso da íntima realidade. (...) como na admirável invenção de Brás Cubas, e todas as vezes que a sua rica imaginação

eISSN: $2179-8478$

DOI: $10.17851 / 2179-8478.11 .123-176$ 
se deu largas para fora da realidade vulgar, sob os artifícios e os mesmos desmandos da fantasia, sentimos a verdade essencial e profunda das cousas, poderíamos chamar-lhe um realista superior, se em literatura o realismo não tivesse sentido definido. (VERÍSSIMO, p.185, 2002)

Antônio Cândido, por sua vez, reverbera similar inflexão, quando aproxima Machado ao expoente do realismo, Émile Zola: “[...] num momento em que Zola preconizava o inventário maciço da realidade, ele [Machado] cultivou livremente o elíptico, o fragmentário, intervindo na narrativa com bisbilhotice saborosa [...]" (CÂNDIDO, 2004, p.22). Ao sabor aparente do estilo de Machado, subjazeria a realidade, capturada por uma espécie de relativismo de tom pessimista (p.13). Seria necessário também, segundo Cândido, distinguir a narrativa aparente das intenções do autor com a finalidade de prevenir certo efeito lisonjeiro imediato:

[...] os leitores sublinhavam também o pessimismo, o grande desencanto que emana das suas histórias. Que não há dúvida é que essas primeiras gerações encontraram nele uma "filosofia" bastante ácida para dar impressão de ousadia, mas expressa de um modo elegante e comedido, que tranquilizava e fazia da sua leitura uma experiência agradável e sem maiores consequências. Poder-se-ia dizer que ele lisonjeava o público mediano, inclusive os críticos, dando-lhes o sentimento de que eram inteligentes a preço módico. (CÂNDIDO, 2004, P.1819)

Nesse mesmo esteio, Roberto Schwarz, em Um Mestre na Periferia do Capitalismo, prolonga a suspeita de que a filosofia de Brás Cubas confirma mais do que desfaz a vaidade de seu público cativo - a elite imperial. Para o crítico, Cubas não passaria de um "um narrador voluntariamente importuno e sem credibilidade" (SCHWARZ, 2000, p.15) dotado de uma "cultura geral caricata, uma espécie de universalidade de pacotilha, na melhor tradição pátria, em que [...] toma como província a experiência global da humanidade e se absolutiza" (p.23). Conviria, portanto, procurar por outras camadas, mais profundas, de leitura. Desse modo, interessado em investigar a

eISSN: 2179-8478

DOI: $10.17851 / 2179-8478.11 .123-176$ 
crítica machadiana da sociedade capitalista periférica, Schwarz considera necessário operar uma cisão entre a forma do romance, composta pelo autor; e seu conteúdo, descrito pelo narrador em primeira pessoa com vistas a:

[...] entrever as grandes linhas de uma estrutura social. São estas que dão a terceira dimensão, ou integridade romanesca, ao brilho algo fácil dos gracejos de primeiro plano. Difícil de precisar, esta unidade latente é um segredo da obra machadiana. (p.14, grifo do autor).

Para Schwarz, o segredo encerrado pela forma adotada por Machado no romance corresponderia ao princípio da volubilidade. O estilo volúvel de Brás Cubas - passando do enciclopedismo "de pacotilha" ao prosaísmo, da galhofa à melancolia, da superioridade à mediocridade, para culminar no desprezo de tudo, a começar pelo leitor corresponderia ao rigor formal através do qual revelar-se-ia, para além das aparências, certa condição paradoxal da elite brasileira da época, assentada na contraditória opção pelo discurso liberal em uma estrutura essencialmente conservadora, latifundiária e escravocrata. Para Schwarz, Machado, ao ter pretendido narrar tal sociedade sob a ótica do defunto autor, teria buscado romper a última exigência de solenidade retórica, liberando desse modo a Brás Cubas o livre exercício do "capricho despótico" (p.22), isto é, da perversidade autoritária da volubilidade que consistiria em livremente contradizerse por puro gozo do exercício de dominação. Desse modo, ainda que a condição póstuma do narrador, único elo com a realidade retratada, seja um inverossímil, tal fato "não desmancha a verossimilhança realista, embora a desrespeite. Antes a confirma [...] Menos que afirmar outro mundo, Brás quer destratar o nosso, que é dele também, isto para infligir-nos a sua impertinência.” (p.15). A perversidade do defunto autor na execução dessa espécie de realismo impertinente, autoritário, melhor expressar-se-ia na relação que estabelece com o seu leitor. Intocável em sua condição póstuma, Brás Cubas não se

eISSN: $2179-8478$

DOI: $10.17851 / 2179-8478.11 .123-176$ 
eximiria de deplorar a situação do leitor, que perdera sua última dignidade: o poder de questionar o narrador acerca da autoridade e da verossimilhança.

Conclui-se que, para Schwarz, a forma do romance realizaria um movimento específico de incorporação ou interiorização da realidade no plano ficcional. Dessarte, vê pertinência em questionar como, para além de Brás Cubas, via Machado de Assis o mundo. A autoridade de que careceria o narrador é, mediante investimento crítico, atribuída ao escritor, cuja visada excederia. É na conformação e desajuste do autor com seu tempo - mais do que na ficção narrada - que residiria o verdadeiro inconfessável da obra, portanto, sua qualidade última, que cumpre ser investigada.

Ao transpor para o estilo as relações sociais que observava, ou seja, ao interiorizar o país e o tempo, Machado compunha uma expressão da sociedade real, sociedade horrendamente dividida, em situação muito particular, em parte inconfessável, nos antípodas da pátria romântica. O "homem do seu tempo e do seu país”, deixava de ser um ideal e fazia figura de problema. (p.9)

Em seu turno, Décio Pignatari teria optado por uma leitura francamente divergente da obra. Seu interesse residiria, sobretudo, no trabalho tipográfico, mais especificamente, a tipoideografia elaborada por Machado de Assis, que saturaria com "rabiscos" o código puramente fonético do alfabeto (PIGNATARI, 2004, p.134) ${ }^{1}$. Para Pignatari, Memórias Póstumas de Brás Cubas, dada sua consciência da dimensão não-verbal e visual do signo, poderia, ao lado de Tristram Shandy, de Lawrence Sterne, ser considerada como exemplo dos primeiros esboços de uma nova prática literária anti-narrativa.

Ainda que a análise semiótica de Pignatari dê ênfase ao signo em si, destacado de implicações narrativas; ela surpreendentemente retoma similar apologia ao autor. Para o crítico, Machado de Assis - que de fato trabalhara na tipografia de Francisco de Paula Brito - "não foi um escritor alienado do médium que utilizava - a palavra impressa,

\footnotetext{
${ }^{1}$ Pignatari refere-se ao uso de paronomásias, jogos tipográficos e rabiscos que intercedem ao longo de todo o livro, como por exemplo, a letra $V$ traçada no capítulo CXLII, "O Pedido Secreto". (ASSIS, 2008, P.29).
}

eISSN: $2179-8478$

DOI: $10.17851 / 2179-8478.11 .123-176$ 
mecânica e industrialmente" (p.133). Desse modo, a erupção do ideograma na página não passaria de "uma forma de mensagem cifrada machadiana, tendo em vista o vitorianismo - e o seu próprio pudor - da época e do ambiente" (p.142) ${ }^{2}$. Retoma desse modo similar padrão de resposta ao atribuir à biografia e psicologia de Machado, e não ao plano ficcional, o significado último dos traços mais marcantes da obra.

Todas essas críticas elucidam aspectos importantes da obra; são elas que melhor aprofundaram nossa compreensão acerca do realismo enviesado de Machado de Assis e sua ampla galeria de personagens memoráveis. Através delas aprendemos quem Machado foi, em qual sociedade vivera e qual a importância de seu trabalho para o cânone literário brasileiro. Porém, se retomarmos a prevenção inicial do autor Machado de Assis - cujo eco de prontidão remonta a Luigi Pirandello e Roland Barthes - e perguntarmos qual interesse efetivo o próprio Brás Cubas eventualmente teria na tipografia, ou ainda, na verdade profunda, no realismo, e/ou no relativismo... - veremos que a resposta permanece, ainda, em silêncio. Em outras palavras, resta perguntar tudo aquilo que não pode ser remetido à biografia, à psicologia e ao momento histórico vivido por Machado de Assis. A começar pela própria consistência do mistério de um romance que, sabe-se lá como, fora escrito do além.

\section{Um pedaço de papel}

\footnotetext{
${ }^{2}$ Outra indagação recorrente no paradigma médio da fortuna crítica de Machado coteja o que nele poderia ser considerado traço especificamente brasileiro, haja visto a universalidade de temas que aborda. Questão que Machado de Assis tivera oportunidade de responder com o célebre mote que diz que todo escritor pode ser "homem do seu tempo e do seu país, ainda quando trate de assuntos remotos no tempo e no espaço" (ASSIS cit. por SCHWARZ, 2000, p.8). Tal questão - a brasilidade - pode ter influenciado também na opção pela "política do autor", haja visto que, segundo o silogismo, Brás Cubas, sendo tão somente um tipo brasileiro, não poderia tipificar sua própria condição como tal.
}

eISSN: 2179-8478

DOI: $10.17851 / 2179-8478.11 .123-176$ 
Que interesse Brás Cubas teria, portanto, em escrever um romance? Escreverá outro? Não sabemos precisamente.

Em todo caso, aprecia romances. Cita-os sempre quando pode, ao lado de filósofos, poetas, teólogos. Aprecia, sobretudo, a volúpia do aborrecimento (p.36) que lhe acomete ao lê-los, solitariamente - passar a tarde "jururu", contemplando a dor no peito taciturna. Aprecia também o livro, a página, a letra - o acabamento e as estampas, os caracteres tipográficos, o negrito e o itálico, a caixa alta e versalete. Tem estima pelo livro e todos seus adornos; em sua bela sala de estudos, como glosa ao grande feito, um busto em bronze de Voltaire, do qual desponta do olhar um risinho de sarcasmo. Escrever, para Cubas, é dosar o texto com medida de elegância da mancha gráfica: "Capítulos compridos quadram melhor a leitores pesadões; e nós não somos um público in-folio, mas in-12, pouco texto, larga margem, tipo elegante, corte dourado e vinhetas..." (p.34).

Não apenas livros: Brás Cubas aprecia, sobretudo, letras inscritas na superfície, quaisquer que sejam o formato e intenção. Há um miríade delas por todo romance. Enumeramos: o epitáfio de Dona Eulália, solenemente transposta à página com adequada tipografia (p.119), ocupando o espaço de todo um capítulo. O nome Oblivion, disposto em versalete, para tecer homenagem ao esquecimento (p.124). Os diacríticos de enorme potencial expressivo, que assumem a tarefa de narrar nos capítulos CXXXIX "De Como Não Fui Ministro D’Estado” (p.126) e LV “O Velho Diálogo de Adão e Eva” (p.62). Diversos bilhetes, muitos deles transcritos cuidadosamente, os quais Cubas relia três, quatro, infinitas vezes. Entre eles, o bilhete misterioso cuja assinatura, apenas uma letra $\mathrm{V}$, passada em revista "não era a letra fina e correta de Virgília, mas grossa e desigual; o

eISSN: $2179-8478$

DOI: $10.17851 / 2179-8478.11 .123-176$ 
V da assinatura não passava de um rabisco sem intenção alfabética; de maneira que, se a carta aparecesse, era muito difícil atribuir-lhe a autoria" ${ }^{\prime 3}$ (ASSIS, 2008, P.129).

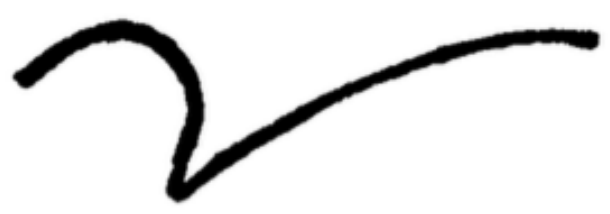

Também, cartas de juventude, que convém serem guardadas para que se contemple a "filosofia das folhas velhas" (p.112). E o bibliômano, cujo exame minucioso da página tem por hábito "desengonçar” a matéria das palavras:

lê, relê, treslê, desengonça as palavras, saca uma sílaba, depois outra, mais outra e as restantes, examina-as por dentro e por fora, por todos os lados, contra a luz, espaneja-as, esfrega-as no joelho, lava-as, e nada; não acha o despropósito. (p.78)

Além disso, há também as folhas públicas, para as quais escreve e da qual se tornará dono. E o Emplasto Brás Cubas, aquele que era sua ideia fixa, a razão última de sua morte; o remédio que eventualmente curaria todos os males possíveis da humanidade mas que serviria-lhe, no íntimo, apenas para saciar sua sede de nomeada, qual seja, "o gosto de ver impressas nos jornais, mostradores, folhetos, esquinas, e enfim nas caixinhas do remédio, estas três palavras: Emplasto Brás Cubas” (p.4).

\footnotetext{
${ }^{3}$ Para Pignatari, V como ideograma de forte carga erótica. (p.137)
} 
Enfim, toda sorte de letras impressas, rabiscos ou gravuras - como aquele pequeno pedaço de papel contra o qual o jovem Brás Cubas lançara-se ansiosamente, enquanto ouvia de seu pai os planos que sua vida burguesa deveria tomar: seguir carreira política; casar-se com certa jovem escolhida.

Eu deixava-me estar ao canto da mesa, a escrever desvairadamente num pedaço de papel, com uma ponta de lápis; traçava uma palavra, uma frase, um verso, um nariz, um triângulo, e repetia-os muitas vezes, sem ordem, ao acaso, assim:

A arma virumque cano

Arma virumque cano arma virumque cano arma virumque arma virumque cano virumque

Maquinalmente tudo isto; e, não obstante, havia certa lógica, certa dedução; por exemplo, foi o virumque que me fez chegar ao nome do próprio poeta, por causa da primeira sílaba; ia a escrever virumque - e sai-me Virgílio, então continuei:

Vir

$$
\begin{array}{ll}
\text { Virgílio } & \text { Virgílio } \\
\text { Virgílio } & \text { Virgílio }
\end{array}
$$

$$
\text { Virgílio }
$$

Meu pai, um pouco despeitado com aquela indiferença, ergueu-se, veio a mim, lançou os olhos ao papel...

- Virgílio! exclamou. És tu, meu rapaz; a tua noiva chama-se justamente Virgília. (p.38-39)

Essa passagem é importante não apenas pelo caráter tipoideográfico da composição, mas também pela relação com a escrita que suscita. Cumpre notar que, com exceção de algumas máximas, seis exemplos de "bocejos de enfado" (p.115), este trecho é a única transcrição literal de um escrito de Brás Cubas quando vivo - curiosamente, ele ocultou a nós todo o resto, seus artigos políticos e poemas. Este pequeno pedaço de papel,

eISSN: $2179-8478$

DOI: $10.17851 / 2179-8478.11 .123-176$ 
detalhado minuciosamente: que interesse tem ele? Ainda que desprovido de sentido, sua garatuja, por puro acaso - e misteriosamente - converge ao fim com seu próprio destino.

Estranha relação com o destino. A necessidade da garatuja advém, senão, da mera angústia em ser confrontado com o destino; e expressa-se no papel como puro semsentido (ainda que porte certa lógica misteriosa). A completa falta de sentido das formas e frases, acompanhadas pela latência secreta da ambição fálica (cano/arma; poeta), são, por assim dizer, a forma cifrada de expressão desse destino; perante sua própria vida que se anuncia pelos projetos do pai, o jovem, malgrado os planos e conjecturas que lhe preparam, experimenta no íntimo nada mais que uma espécie de puro virumque vir. Curioso destino dado para a personagem da Divina Comédia, de Dante: o poeta Virgílio, outrora guia do herói no inferno, reaparece aqui como mero desdobramento do rabisco coincidindo, por acaso, com o improvável destino que se anuncia.

No romance de Brás Cubas, garatujas, diacríticos, caracteres tipográficos, transcrições literais de textos de outros suportes tais como lápides e toda sorte de maquinário escritural assumem a função de narrar um determinado evento. Com efeito, podemos de imediato notar certa intimidade da sociedade burguesa que fizera da letra e da imprensa seu melhor meio de expressão. Ao ocultar seus escritos artísticos e filosóficos; ao transcrever tantos outros papeis sem importância aparente; e, enfim, ao confessar a sua sede de nomeada, o desejo de ver-se o nome impresso em toda sorte de meios; Brás Cubas parece requerer ao leitor especial atenção para toda sorte de experiências um pouco secretas, muitas vezes incompreensíveis e até mesmo tolas de leitura e escrita em seu amplo espectro de possibilidades. Mais do que pelo conteúdo que veiculam, esses pedaços de papel importam sobretudo pelas sensações que emanam, pela forma como vemos neles consumida a ânsia de glória ou a chama da vida. Abundam, a esse respeito, diversas teses: a "filosofia das folhas velhas"; a "volúpia do aborrecimento"; a "sede de nomeada"; os "rabiscos sem intenção alfabética"; "público in-

eISSN: $2179-8478$

DOI: $10.17851 / 2179-8478.11 .123-176$ 
12"; a teoria da "solda" do livro da vida (p.110); a teoria da "errata pensante" (p.39) e das “edições humanas" (p.39; p.47) etc.

O capítulo “CVIII - Que Se Não Entende” melhor explicita a função evocativa de sensações desses pedaços de papel. Brás Cubas, logo após transcrever exatamente um deles no capítulo "CVII - O Bilhete", comenta:

\begin{abstract}
Eis aí o drama, eis aí a ponta da orelha trágica de Shakespeare. Esse retalhinho de papel, garatujado em partes, machucado das mãos, era um documento de análise, que eu não farei neste capítulo, nem no outro, nem talvez em todo o resto do livro. Poderia eu tirar ao leitor o gosto de notar por si mesmo a frieza, a perspicácia e o ânimo dessas poucas linhas traçadas à pressa; e por trás delas a tempestade de outro cérebro, a raiva dissimulada, o desespero que se constrange e medita, porque tem de resolver-se na lama ou no sangue, ou nas lágrimas? (p.36)
\end{abstract}

As sensações são a iguaria mais fina de um livro, para o leitor; e o poder das garatujas em evocá-las vem em socorro, justamente, às deficiências que a escrita tem ao elaborar certas correspondências entre as mais difusas e contraditórias sensações. Termina desse modo o capítulo, concluindo que talvez tivesse sido melhor ter ficado apenas com o bilhete:

Quanto a mim, se vos disser que li o bilhete três ou quatro vezes, naquele dia, acreditai-o, que é verdade; se vos disser mais que o reli no dia seguinte, antes e depois do almoço, podeis crê-lo, é a realidade pura. Mas se vos disser a comoção que tive, duvidai um pouco da asserção, e não a aceiteis sem provas. Nem então, nem ainda agora cheguei a discernir o que experimentei. Era medo, e não era medo; era dó e não era dó; era vaidade e não era vaidade; enfim, era amor sem amor, isto é, sem delírio; e tudo isso dava uma combinação assaz complexa e vaga, uma coisa que não podereis entender, como eu não entendi. Suponhamos que não disse nada. (p.107, grifo do autor)

O gosto de notar por si mesmo as sensações, de experimentá-las é, repassado as minúcias, o verdadeiro objetivo almejado pelo romancista; ele quer presentear o leitor com sensações; e seu romance, aqui, se equipara em estatura aos pedaços de papel que nos cercam.

eISSN: $2179-8478$

DOI: $10.17851 / 2179-8478.11 .123-176$ 


\section{Edição Definitiva, Exemplar Único, Coisa Nenhuma}

Entretanto, Brás Cubas não apenas celebra as experiências furtivas de contemplação da letra escrita, a capacidade que qualquer rabisco num papel tem de reorientar nossas reminiscências e proporcionar-nos sensações. Para ele, as páginas coincidem, de algum modo, com a própria vida; são, por assim dizer, sua matéria duplicada.

Tome-se, por exemplo, a curiosa relação entre a dedicatória do livro e a teoria das edições humanas. A teoria diz: "Cada estação da vida é uma edição, que corrige a anterior, e que será corrigida também, até a edição definitiva, que o editor dá de graça aos vermes." (p.7). E a dedicatória, diz: "ao verme que primeiro roeu as frias carnes do meu cadáver dedico como saudosa lembrança estas Memórias Póstumas" (p.1). Vida e memória, aqui, têm como elo comum a morte ou, mais especificamente, a prolongada e definitiva ação do verme.

O livro que temos em mãos corresponde à edição definitiva da vida? Assim diz o capítulo CXXXVIII - "A Um Crítico":

\section{Meu caro Crítico,}

Algumas páginas atrás, dizendo eu que tinha cinquenta anos, acrescentei: "Já se vai sentindo que o meu estilo não é tão lesto como nos primeiros dias". Talvez aches esta frase incompreensível, sabendo-se o meu atual estado; mas eu chamo a tua atenção para a sutileza daquele pensamento. O que eu quero dizer não é que esteja agora mais velho do que quando comecei o livro. A morte não envelhece. Quero dizer, sim, que em cada fase da narração da minha vida experimento a sensação correspondente. Valha-me Deus! é preciso explicar tudo. (p.126, grifo do autor)

Através deste capítulo nós, críticos, devemos compreender que para Brás Cubas não há simples linearidade entre sua vida e o livro que escreve. Pelo contrário, entre essas memórias e a vida passada há, tão somente, uma correspondências de sensações - que se prologam no tempo inerte da morte. O livro não é ato tampouco imagem definitiva

eISSN: $2179-8478$

DOI: $10.17851 / 2179-8478.11 .123-176$ 
daquela vida; recolhe, simplesmente, algumas poucas reminiscências para que se experimente as sensações correspondentes. A morte não lhe trouxe a compreensão inequívoca da vida mas, tão somente, a possibilidade de se traçar as correspondências entre as múltiplas estações e edições da vida.

Há certo titubear nas reflexões de Brás Cubas acerca de seu passado. Por vezes, chega a contradizer-se num mesmo parágrafo - como no capítulo "LXXIX Compromisso", onde escreve: "por fim interveio um compromisso entre o egoísmo e a piedade. (...) Agora, que isto escrevo, quer-me parecer que o compromisso era uma burla, que essa piedade era ainda uma forma de egoísmo” (p.84, grifo do autor). Tal continua indefinição - que contrapõe o que se pensara vivo com aquilo que se pensou no plano póstumo e até mesmo com aquilo que se pensa durante o ato de escrita - ressalta o aspecto do labor reminiscente (difuso, vago, cambiante) em detrimento de uma eventual autoridade inequívoca do narrador onisciente. Com efeito, o fato de ser um defunto autor não o aproximou da verdade mas ressaltou certas vicissitudes inerentes à reminiscência. É sob o efeito de torpor das reminiscências que ele, como diz, tem o estilo de narrar semelhante ao dos "ébrios, [que] guinam à direita e à esquerda, andam e param, resmungam, urram, gargalham, ameaçam o céu, escorregam e caem..." (p.78). As reminiscências insinuam, no espaço inerte da morte, uma tessitura precária e correspondente da vida; no livro - prolongamento objetivo dessa inércia - se fixam as saudosas lembranças.

Pois que o interesse de Brás Cubas não está em compor a edição definitiva e integral da vida passada. Quer, pelo contrário, converter sua vida - de quem fora o único exemplar - em uma espécie de exemplar único de livro.

A sequência de capítulos "LXXI - O Senão do Livro" e "LXXII - O Bibliômano" elucidam de maneira enviesada o mistério particular do livro que temos em mãos, escrito por um defunto autor. Assim termina aquele capítulo em que comparara seu estilo aos ébrios:

eISSN: $2179-8478$

DOI: $10.17851 / 2179-8478.11 .123-176$ 
E caem! - Folhas misérrimas do meu cipreste, heis de cair, como quaisquer outras belas e vistosas; e, se eu tivesse olhos, dar-vos-ia uma lágrima de saudade. Esta é a grande vantagem da morte, que, se não deixa boca para rir, também não deixa olhos para chorar... Heis de cair. (p.78, grifo do autor)

Já no capítulo seguinte, Brás Cubas adverte-nos acerca do capítulo anterior:

Talvez suprima o capítulo anterior; entre outros motivos, há aí, nas últimas linhas, uma frase muito parecida com despropósito, e eu não quero dar pasto à crítica do futuro. (p.78)

Em seguida, põe-se a imaginar como um bibliômano qualquer, interessado em descobrir o despropósito, põe-se a investigar acerca desse livro que teria comprado por acaso, num pardieiro:

Achou o volume, por acaso, no pardieiro de um alfarrabista. Comprou-o por duzentos réis. Indagou, pesquisou, esgaravatou, e veio a descobrir que era um exemplar único... Único! Vós, que não só amais os livros, senão que padeceis a mania deles, vós sabeis muito bem o valor desta palavra, e adivinhais, portanto, as delícias de meu bibliômano. (p.78)

Para compreender melhor o despropósito, é preciso compreender o que exatamente está em jogo aqui nesses dois capítulos: uma anedota de abstração. O termo, concebido por Guimarães Rosa, tentava dar conta de certos tipos de anedota, como aquela da criança: “O Verdadeiro Gato. O menino explicava ao pai a morte do bichinho: - 'O gato saiu do gato, pai, e só ficou o corpo do gato"” (ROSA, 2009 p.24). Para Rosa, anedotas de abstração são aquelas que "mais direto colindem com o não-senso, a ele afins; e o não-senso, crê-se, reflete por um triz a coerência do mistério geral, que nos envolve e cria. A vida também é para ser lida. Não literalmente, mas em seu suprasenso." (2009, p.21).

A despropositada anedota de abstração desses capítulos consistem, precisamente, no jogo de paranomásia implícito. Onde o bibliômano viu um exemplar único e se deu por satisfeito; devemos ler que o que temos em mãos é, justamente, o único exemplar das

eISSN: $2179-8478$

DOI: $10.17851 / 2179-8478.11 .123-176$ 
memórias. Assim como na vida, em que deram a um único corpo o nome de Brás Cubas; as reminiscências foram inscritas, misteriosamente, em um único volume ${ }^{4}$. Não havendo mais, após a ação do verme, boca ou olho para dar conta do fenômeno, as páginas misérrimas caem do abstrato cipreste: não da verdade, mas da saudade - o grande compósito de sensações que nos acudem nossas reminiscências. Como enfim podem cair da saudade, do rigoroso nada - eis a abstração da escrita.

Cumpre notar que o único ponto que interliga o plano póstumo à Terra é o corpo à espera de ser carcomido integralmente pelo verme. Com efeito, Brás Cubas ainda pode descrever seu enterro e toda a orquestra da morte que o acompanha. Tudo isto ainda está integrado ao prolongado ato de morrer, que requer a desaparição do corpo: "A vida estrebuchava-me no peito, com uns ímpetos de vaga marinha, esvaía-se-me a consciência, eu descia à imobilidade física e moral, e o corpo fazia-se-me planta, e pedra e lodo, e coisa nenhuma." (p.3). Desse modo, tão logo é atingido o estado de coisa nenhuma, toda ligação com a Terra será desfeita; e Brás Cubas nada dela poderá conhecer ou ver. Não há nenhuma menção a um evento ocorrido na Terra após ter o corpo carcomido; e se imagina que Virgília eventualmente o lerá, não sabe se ainda estará viva (um paradoxo, afinal, diante da eternidade da morte a passagem de tempo faz pouco sentido - "A morte não envelhece" [p.126]): "Tu que me lês, se ainda fores viva, quando estas páginas vierem à luz, - tu que me lês, Virgília amada, não reparas na diferença entre a linguagem de hoje e a que primeiro empreguei quando te vi?" (p.17). Temos, tão somente, as reminiscências e as eventuais sensações que podem repercutir no leitor.

Dessarte, retomando a relação entre a teoria das edições humanas e a dedicatória, depreende-se que o verme é uma espécie de "leitor" ideal da vida e do romance. Porque é

\footnotetext{
${ }^{4}$ Estamos aqui, talvez, diante de um dos casos mais curiosos de ilegibilidade causados pela apologia ao autor. Os críticos, em geral, ignoram essa despropositada anedota; talvez pelo fato de que, interessados tão mais pelo Machado de Assis, esqueceram-se de se perguntar como, de fato, um defunto autor faria para publicar o seu livro do além. Roberto Schwarz, por exemplo, ao comentar o caráter estratégico da "descrença na unicidade ou no insubstituível" (SCHWARZ, p.93), exemplifica-a com o bibliômano "a quem pouco importa o conteúdo dos livros desde que sejam exemplares únicos - certamente insinuando que a unicidade é uma mania entre outras" (p.93, grifo do autor). Obviamente, quem insinuaria que a unicidade não tem valor algum seria o autor, Machado de Assis.
}

eISSN: 2179-8478

DOI: $10.17851 / 2179-8478.11 .123-176$ 
preciso que roa as carnes para que se conclua, enfim, a edição definitiva do "livro da vida". E porque, ao roê-la, abre a possibilidade da atividade pura de reminiscência e, desse modo, abre o frontispício de conversão do único exemplar em um exemplar único de romance. Uma espécie de "palimpsesto": rói-se a vida para escrever o romance (reminiscências); rói-se o romance para ler a vida (sensações correspondentes). Vida também é para ser lida: não literalmente, mas em seu supra-senso. Invocadas pelo verme, vida e memória se reúnem para assimilar o veredicto encerrado no livro-corpo carcomido.

Há, portanto, não linearidade, mas dobra entre reminiscência e vida que, sob efeito do duplo carcomer, se enterram na própria espessura do livro e tornam-se para si objeto da própria narrativa.

\section{A aventura, a estafa e a lazeira}

Dissemos que a ação do verme impõe à vida e às reminiscências que se tornem para si objetos da narrativa. De que modo? Antes de respondermos a essa pergunta, cumpre compreender como Brás Cubas interpreta a relação do gênero romanesco com o verme.

Há uma curiosa passagem de Memórias Póstumas de Brás Cubas na qual o narrador se apresenta mancebo e viril, prestes a cavalgar a vida, por analogia, também a história do romance, gênero literário:

"Ao cabo, era um lindo garção, lindo e audaz, que entrava na vida de botas e esporas, chicote na mão e sangue nas veias, cavalgando um corcel nervoso, rijo, veloz, como o corcel das antigas baladas, que o romantismo foi buscar ao castelo medieval, para dar com ele nas ruas do nosso século. O pior é que o estafaram a tal ponto, que foi preciso deitá-lo à margem, onde o realismo o veio achar,

eISSN: $2179-8478$

DOI: $10.17851 / 2179-8478.11 .123-176$ 
comido de lazeira e vermes, e, por compaixão, o transportou para os seus livros." (ASSIS, 2008, p.21, grifos do autor)

Entretanto, conforme descobriremos ao final do capítulo, não era Brás Cubas assaz tão ousado, nem tão galopante seu cavalo; a comparação sendo apenas mais uma de suas digressões de certo sabor irônico. Da promessa de uma vida épica, digna de romance, advém o parco resultado do cortejo de uma mulher de amores fáceis, Marcela, protagonista de seu primeiro beijo. O “corcel cego do desejo” será logo substituído pelo "asno da paciência" (p.23).

O trecho faz, certamente, alusão aos romances de cavalaria; e o caráter intencionalmente farsesco é, talvez, referencia implícita a Dom Quixote de La Manchao primeiro grande livro do gênero romanesco, para Walter Benjamin. Como no livro de Cervantes; tanto o "garção" protagonista, quanto o cavaleiro medieval que lhe confere o molde, são prolepses falidas e suas aventuras celebram a incompatibilidade do destino com o sentido. A aventura romântica, cruzando os séculos, dera alhures em lugar algum. E o realismo não pode fazer mais do que conservar no livro a triste figura e seu rocinante, estafados, carcomidos e perdidos, deitados à margem da modernidade.

A aventura, porém, tem por função dar entrada na vida. Depreende-se logo que há duas vidas: a vida épica, evocada pela aventura que se anuncia; e outra vida, extrínseca ao romance, vida dos corpos cujo único destino plausível é a morte e que, não podendo representar aquela vida de botas e esporas, estafam-se nalgum momento. $\mathrm{O}$ verme confirma aquilo que a estafa permitia já supor: o caráter puramente representativo da prolepse de uma vida épica; ou ainda, dito sob outra perspectiva, o fato da vida em si, vida dos corpos, ser mera intrusa na aventura romântica. Em resumo, aos olhos da vida épica, a vida dos corpos não é, senão, sintoma de putrefação.

Fora dito que o realismo conserva por compaixão o rocinante carcomido. Depreende-se que, assim como o romantismo não pode ser confundido com o garção e o corcel; não há qualquer correlação direta entre o realismo e o verme. O romantismo está

eISSN: $2179-8478$

DOI: $10.17851 / 2179-8478.11 .123-176$ 
para o desejo assim como o realismo está para a compaixão; e aquele, para a estafa, assim como este para a lazeira. Tanto o corcel estafado quanto o rocinante putrefato são signos que, não obstante animem todo um universo de representação ficcional, carregam em si o estigma da vida - naturalmente incompetente para a aventura épica porque simplesmente expirar antes que o sentido do destino seja alcançado. A analogia que Brás Cubas tece para si com os romances de cavalaria refaz a imagem do próprio homem burguês constrangido, por um lado, pela ânsia de glória e, por outro, pela consciência da frialdade inorgânica da morte ${ }^{5}$.

\section{Metáforas transparentes, preços baratos}

Para Brás Cubas, a vida não é o objeto do romance; mas a incongruência entre a vida épica, que o romance representa, e aquela outra, a vida dos corpos: a prolepse, a estafa e a lazeira. Na segunda parte de Dom Quixote, as personagens sabem que foram protagonistas do primeiro volume; e dizem, a todo momento, que se divertiram muito lendo suas aventuras; Quijano, porém, morrerá logo após cair em si e perceber que todas as aventuras que vivera enquanto Quixote não passavam de insanidades. Brás Cubas compartilha, de algum modo, essa descontinuidade entre vida dos corpos e vida representada quando narra, com compaixão, sua própria vida sob ótica póstuma: a vida, para o morto, é também uma personagem. O romance torna-se à luz dessa incongruência objeto de si mesmo; e à medida que o verme se insinua sobre ambas - a vida -, torna-se

\footnotetext{
${ }^{5}$ Na poesia, poderíamos alinhar, de um lado, Álvarez de Azevedo, conforme os versos de Se eu Morresse Amanhã: "Mas essa dor da vida que devora / A ânsia de glória, o dolorido afã... / A dor no peito emudecera ao menos / Se eu morresse amanhã!". E, de outro, Augusto dos Anjos - conforme os versos de Psicologia de Um Vencido: "Já o verme — este operário das ruínas - / Que o sangue podre das carnificinas / Come, e à vida em geral declara guerra, / Anda a espreitar meus olhos para roê-los, / E há-de deixar-me apenas os cabelos, / Na frialdade inorgânica da terra!"
}

eISSN: 2179-8478

DOI: $10.17851 / 2179-8478.11 .123-176$ 
mais tensa tal incongruência. Retomemos a pergunta: de que modo a ação do verme impõe à vida e às reminiscências que se tornem para si objetos do romance?

No capítulo XXXVIII “A Quarta Edição” há o curioso espetáculo visível do duplo carcomer do corpo e das paixões pelo verme e a reverberação dele no campo das reminiscências.

Àquela altura, Brás Cubas já estava em sua quarta edição:

Pois sabei que, naquele tempo, estava eu na quarta edição, revista e emendada, mas ainda inçada de descuidos e barbarismos; defeito que, aliás, achava alguma compensação no tipo, que era elegante, e na encadernação, que era luxuosa. (ASSIS, 2008, p.47)

O enredo do capítulo possui forte carga simbólica. Ao consultar seu relógio, vê a tampa de vidro cair e espatifar-se. Entra na primeira loja que vê, atrás de nova cobertura; um cubículo estreito e escuro. Nela, ao fundo, entrevê uma figura macilenta que, não obstante aparentasse ter sido bonita na juventude, tem agora o aspecto ruço e carcomido, a doença conferindo-lhe "saliências e encarnas, declives e aclives, e davam uma sensação de lixa grossa, enormemente grossa" (p.48). Da massa disforme desponta um olhar singular e incompreensível: "eram os olhos a melhor parte do vulto, e aliás tinham uma expressão singular e repugnante, que mudou, entretanto, logo que eu comecei a falar." (p.48). Descreve as mudanças: após uma breve tentativa de se esconder (crê, talvez, por instinto da vaidade); o olhar daquela figura passa a assumir uma expressão "meio doce e meio triste" (p.48). Crê Brás Cubas que tais mudanças se deram por ter sido reconhecido logo. Pois que reconhecera, enfim, o vulto de Marcela - que lhe pergunta: "quer comprar alguma coisa?"(p.48). Brás Cubas, atônito, não consegue responder-lhe; ante seu silencio resta Marcela, hesitante, e Cubas pensa se seu silêncio era devido "o assombro do presente, se a memória do passado" (p.48).

Discutem os dois os infortúnios da vida, particularmente difícil para Marcela, quem sofrera diversos contratempos; e desinteressante, para Brás Cubas, que ainda não havia se casado. Se examinam atentamente; lhes acodem reminiscências. Para Cubas,

eISSN: $2179-8478$

DOI: $10.17851 / 2179-8478.11 .123-176$ 
entretanto, elas servem menos pelas imagens que elaboram do que para medir o valor daquela paixão que sentira outrora:

Não era esta certamente a Marcela de 1822; mas a beleza de outro tempo valia uma terça parte dos meus sacrifícios? Era o que eu buscava saber, interrogando o rosto de Marcela. O rosto dizia-me que não; ao mesmo tempo os olhos me contavam que, já outrora, como hoje, ardia neles a flama da cobiça. Os meus é que não souberam ver-lha; eram olhos da primeira edição. (p.49, grifo do autor)

Continuando a reflexão, termina o capítulo:

Disse ela então que desejava ter a proteção dos conhecidos de outro tempo; ponderou que mais tarde ou mais cedo era natural que me casasse, e afiançou que me daria finas joias por preços baratos. Não disse preços baratos, mas usou uma metáfora delicada e transparente. Entrei a desconfiar que não padecera nenhum desastre (salvo a moléstia), que tinha o dinheiro a bom recado, e que negociava com o único fim de acudir à paixão do lucro, que era o verme roedor daquela existência; foi isso mesmo que me disseram depois. (p.49)

Marcela é, aparentemente, uma figura duplamente carcomida pelo verme - seja pela moléstia; seja pela paixão do lucro. E aparentemente Marcela padecera somente da moléstia, pois tinha pela cobiça estima. Sobressai, aqui, o destaque, em itálico, que o narrador confere ao termo preços baratos. Subentendido através de uma metáfora delicada e transparente; o preço barato ${ }^{6}$ é senão uma espécie de sintoma de uma força inabalável que, superior ao homem e seus eventuais desastres, anima o viver ao mesmo tempo que lhe rói a vida.

Com efeito, se há uma incongruência entre uma vida representada por metáforas delicadas e transparentes e a vida dos corpos, cuja ânsia de glória os faz se sentirem

\footnotetext{
${ }^{6}$ Poder-se-ia dizer que o preço barato é, senão, uma última metáfora para a relação de Brás Cubas e Marcela que, no início, era regada de joias caras as quais ela até mesmo certa vez chegou a recusar. Entretanto, para dizê-lo, seria necessário recorrer à apologia do autor, isto é, reconhecer que as memórias de Brás Cubas não passariam de uma longa cadeia de metáforas manejadas por Machado de Assis para construir, de modo enviesado, a imagem realista da sociedade em que vivera. Com efeito, o que este capítulo põe em suspeita é, justamente, a relação da metáfora com a ação concreta do verme.
}

eISSN: 2179-8478

DOI: $10.17851 / 2179-8478.11 .123-176$ 
estafados e carcomidos; só é possível avaliar o valor da relação entre vida épica e vida dos corpos à medida que se aproxima do embate final entre a chama e a frialdade inorgânica. É preciso que o tempo seja destampado, isto é, posto em contato diretamente consigo mesmo para que se possa, enfim, reunir as reminiscências com o objetivo de auferir valor. Marcela não valera a terça parte dos esforços - e dos gastos - porque, enfim, ficara feia; e, talvez, o mesmo valesse para Brás Cubas, a quem Marcela julgara ser o caso, por ele não ter atingido a glória e fortuna, de vender joias por preços baratos.

Ao contrário do que eventualmente poder-se-ia ver no quadro de Dorian Gray; Marcela não é, dada sua decrepitude, uma imagem mais perfeita e acabada do lucro e da cobiça. Entretanto, é devido ao forte contraste entre a beleza exaurida pela moléstia em formas macilentas e a vivacidade daquilo que desponta através do olhar ardente, singular e repugnante, que se permite supor os fundamentos daquela vida. $\mathrm{O}$ jogo de olhares entre Cubas e Marcela - animado por metáforas dissimuladas, delicadas e transparentes (como é, de certa forma, a própria superfície do olho) - é o único sintoma visível da chama que os alimenta e consome.

O olho e a boca - que a morte oferece a vantagem de não mais possuí-los aparecem mais de uma vez no romance para tratar dessa súbita visada integral reminiscente que nos acometem os estados moribundos. Vê seu pai, prestes a falecer, soltar um riso de outrora e assumir nos olhos "uma concentração de luz que era, por assim dizer, o último lampejo da alma expirante" (p.86). E quando era ele próprio o moribundo, vira Virgília:

De pé, à cabeceira da cama, com os olhos estúpidos, a boca entreaberta, a triste senhora mal podia crer na minha extinção.

— "Morto! morto!" dizia consigo.

E a imaginação dela, como as cegonhas que um ilustre viajante viu desferirem o voo desde o Ilisso às ribas africanas, sem embargo das ruínas e dos tempos... (p.3, grifo do autor)

eISSN: $2179-8478$

DOI: $10.17851 / 2179-8478.11 .123-176$ 
A necessidade de se ler outra vez (morto! morto!) esta espécie de enigma engramático que, ardente, trespassa o olhar e entreabre as metáforas transparentes em toda sua incongruência com a vida dos corpos é, precisamente, o modo pelo qual as reminiscências e a vida tornam-se para si, sob efeito da ação do verme, objetos da narrativa que elaboram.

\section{Enxurro da vida, enxurro perpétuo}

Daí advém, talvez, a impressão de que a vida, considerada como elemento ao mesmo tempo extrínseco e relativo ao homem - este capturado pelo embate entre o que é épico e o que é somente putrefaciente -, surja como uma força imensa e inequívoca: perpétuo enxurro. E de que somente as reminiscências, especialmente aquelas que nos acodem quando defrontamos com algum sintoma de envelhecimento ou morte e, sobretudo, aquelas abertas por uma condição póstuma, sejam a linguagem adequada para elaborar como o excesso da vida insiste sobre o homem. Experimentar nessas ocasiões as próprias reminiscências é como uma espécie de voo do naturalista convertido num pássaro $^{7}$ a sobrevoar as camadas geológicas que o viver impõe à vida.

Brás Cubas, ao revisitar sua pátria, diz:

Vim. Não nego que, ao avistar a cidade natal, tive uma sensação nova. Não era efeito da minha pátria política; era-o do lugar da infância, a rua, a torre, o chafariz da esquina, a mulher de mantilha, o preto do ganho, as coisas e cenas da meninice, buriladas na memória. Nada menos que uma renascença. O espírito, como um pássaro, não se lhe deu da corrente dos anos, arrepiou o voo na direção da fonte original, e foi beber da água fresca e pura, ainda não mesclada do enxurro da vida.

Reparando bem, há aí um lugar-comum. (p.34, grifos do autor)

\footnotetext{
7 “(...) e eu perguntava a mim mesmo o que diriam de nós os gaviões, se Buffon tivesse nascido gavião...” (p.8) Referência a Georges-Louis Leclercq, conde de Buffon, naturalista francês do século XVIII.
}

eISSN: 2179-8478

DOI: $10.17851 / 2179-8478.11 .123-176$ 
Aqui, podemos distinguir e correlacionar reminiscência, sensações e vida. Há uma vida extrínseca, fonte original; e outra, ainda extrínseca porém relativa ao viver, enxurro da vida. As reminiscências correspondem aos sulcos que o enxurro da vida burila na memória. As sensações são o modo através do qual se percorre o caminho inverso, do enxurro à fonte, eventualmente mesclando-os como efeito de renascimento. E, por fim, a despeito da importância para aquele que as sente, o fraco poder enunciativo das sensações em muito às aproxima de lugares-comuns.

Desse modo, quando Brás Cubas diz que, apesar da condição inerte de sua vida póstuma, seu estilo corresponde às diversas sensações que surgem entremeio às reminiscências, ele está, de certo modo, elaborando o mistério das saudosas lembranças dedicadas ao verme, o caráter de sua escrita póstuma: não é apenas porque se lembra, mas sobretudo por que sente saudades (e as sente sem olho, boca ou lágrimas - como pura sensação abstrata) que tornara-se capaz de expedir magros capítulos do além; e não crê Brás Cubas haver outro desejo por parte do leitor que, senão, saborear, assim como ele, ou talvez até mais do que ele, tais sensações. O romance tem por função elaborar, através das reminiscências, as sensações que melhor correspondam àquilo que, para o vivo, permanece indecifrável: o enxurro da vida. Entretanto, as sensações não possuem o poder de explicar o transcorrer da vida, de representar a face integral do destino; as sensações tem, simplesmente, o poder de representar a decomposição de uma vida em detrimento $d a$ vida - em resumo, os lugares-comuns que a um homem é dado a frequentar.

Há um outro trecho em que Brás Cubas retoma sua reflexão acerca do enxurro da vida. Aqui, porém, desligada diretamente das sensações e do assombro das reminiscências - e desligada, portanto, do próprio romance. Ao analisar Lobo Neves, marido de Virgília, sua amante, diz:

Tudo se deve dizer: havia no Lobo Neves certa dignidade fundamental, uma camada de rocha, que resistia ao comércio dos homens. As outras, as camadas

eISSN: $2179-8478$

DOI: $10.17851 / 2179-8478.11 .123-176$ 
de cima, terra solta e areia, levou-lhas a vida, que é um enxurro perpétuo. Se o leitor ainda se lembra do capítulo XXIII, observará que é agora a segunda vez que eu comparo a vida a um enxurro; mas também há de reparar que desta vez acrescento-lhe um adjetivo - perpétuo. E Deus sabe a força de um adjetivo, principalmente em países novos e cálidos. (p.91)

Ao dizer de um enxurro perpétuo, Brás Cubas inverte a relação que estabelecera outrora ao distinguir a fonte original do enxurro da vida. É que aqui a compreensão do enxurro não diz mais respeito ao ponto de vista subjetivo das reminiscências e à composição de tramas de sensações; e sim, à moral. Do ponto de vista da moral, não há distinção segura entre as fontes da vida e os meandros do viver; há tão somente resistência de caráter. Continua Brás Cubas:

O que é novo neste livro é a geologia moral do Lobo Neves, e provavelmente a do cavalheiro, que me está lendo. Sim, essas camadas de caráter, que a vida altera, conserva ou dissolve, conforme a resistência delas, essas camadas mereceriam um capítulo, que eu não escrevo, por não alongar a narração. (p.91, grifo do autor)

Vale mencionar que Brás Cubas, em sua hermética e profundamente solitária condição póstuma - para quem não há mais nenhum contato com o mundo vivo (de fato, ele ignora completamente o que pode ter acontecido na Terra após seu corpo ter sido carcomido completamente pelo verme) -, não sente a menor necessidade de sentir remorso ou arrependimento por ter sido ele, junto com Virgília, os agentes da mais vigorosa torrente desse "enxurro da vida" lançada contra Lobo Neves.

Porém, o fato de Brás Cubas ser um homem sem caráter talvez não seja a única razão para que exima do papel de agente do enxurro da vida contra Lobo Neves. Há outra: o fato de que a relação dos amantes com Lobo Neves jamais atingira uma só nota trágica. A relação assaz respeitosa, circunscrita à previsibilidade dos bons e respeitosos modos de convívio social, confirma a falta de protagonismo de Cubas.

Vale aprofundar, desse modo, algumas situações em que os amantes se confrontaram com a questão da descoberta da traição, pois ela elucida outros aspectos da

eISSN: 2179-8478

DOI: $10.17851 / 2179-8478.11 .123-176$ 
morte e do enxurro da vida. Há aquele momento em que Cubas e Virgília são surpreendidos por Lobo Neves na casa de D. Plácida, que lhes fazia função de alcova. Neves não chega a ver Cubas, que permanecera escondido; e este, após assistir imóvel a conversa do casal com D. Plácida, pergunta-se:

Respirei e sentei-me. D. Plácida atroava a sala com exclamações e lástimas. Eu ouvia, sem lhe dizer coisa nenhuma; refletia comigo se não era melhor ter fechado Virgília na alcova e ficado na sala; mas adverti logo que seria pior; confirmaria a suspeita, chegaria o fogo à pólvora, e uma cena de sangue... Foi muito melhor assim. Mas depois? que ia acontecer em casa de Virgília? matá-laia o marido? espancá-la-ia? encerrá-la-ia? expulsá-la-ia? Estas interrogações percorriam lentamente o meu cérebro, como os pontinhos e vírgulas escuras percorrem o campo visual dos olhos enfermos ou cansados. Iam e vinham, com o seu aspecto seco e trágico, e eu não podia agarrar um deles e dizer: és tu, tu e não outro. (p.106, grifo do autor)

$\mathrm{Na}$ ânsia de ser confrontado verdadeiramente com o elemento trágico - ver confirmada sua vida épica -, Brás Cubas repete o mesmo padrão daquele pedaço de papel repleto de garatujas virumque vir. Confrontado pela vida real no limite da vida épica, é tomado pela paralisia e vê esvair diante de si todo sentido possível. Tudo decai nas pustulentas formas de sensação ou "sensacionais" que, como tal, meros diacríticos turvos e ilegíveis, são a expressão da vida aos enfermos e cansados, aos lazarentos e estafados. Esse aspecto subitamente moribundo da aventura da vida épica convida a Brás Cubas, novamente, perguntar se valera realmente a pena ter ansiado por vivê-la: "Em verdade, as aventuras são a parte torrencial e vertiginosa da vida, isto é, a exceção; eu estava enfarado delas; não sei até se me pungia algum remorso.” (p.106) Em oposição, passa a imaginar-se vivendo uma perfeita e tediosa vida burguesa: casado e pai, balançando-se numa idílica chácara a contemplar uma nesga de céu azul... isto é: um final feliz.

Outro "clímax" 8 do romance é o momento em que Lobo Neves recebe uma carta denunciando, de fato, os dois amantes. Trata-se de um dos capítulos mais vagos de todo o

\footnotetext{
${ }^{8}$ Extremamente difícil utilizar esse termo para Memórias Póstumas de Brás Cubas. Não há um único "clímax” típico que não seja logo após imediatamente relativizado com alguma rabugem. Tal é a característica do romance: tudo aquilo que eventualmente teria a função de clímax decai rapidamente para um evento de qualidade desinteressante e
}

eISSN: 2179-8478

DOI: $10.17851 / 2179-8478.11 .123-176$ 
livro; nele, há pouco mais que imaginações e indagações acerca do que poderia ter acontecido e sido. Brás Cubas logo confessa não se lembrar bem de como estava Lobo Neves naquela manhã; recorda-se apenas de que estava frio e taciturno e de que talvez tenha lhe passado pela cabeça esbofeteá-lo, pois se lembra de algo como um gesto furtivo, contido. Mais tarde, enquanto Virgília lhe narrava o momento em que seu marido lhe mostrara enfim a anônima carta, Brás Cubas se vê imaginando o que poderia ter passado pela cabeça do homem traído. Por fim, notando que Virgília narrava tudo sem qualquer sintoma de desespero ou terror; e Virgília, por sua vez, notando em Cubas similar empáfia; olham-se francamente e se perguntam: o que viveram valeu a pena? Ao que Virgília diz: “- Você não merece os sacrifícios que lhe faço.” (p.100); e Brás Cubas, em silêncio, conclui:

Não lhe disse nada; era ocioso ponderar-lhe que um pouco de desespero e terror daria à nossa situação o sabor cáustico dos primeiros dias; mas se lho dissesse, não é impossível que ela chegasse lenta e artificiosamente até esse pouco de desespero e terror. Não lhe disse nada. Ela batia nervosamente com a ponta do pé no chão; aproximei-me e beijei-a na testa. Virgília recuou, como se fosse um beijo de defunto. (p.100, grifo do autor)

Lobo Neves, a quem a "ponta de orelha trágica de Shakespeare" (p.107) poderia eventualmente acudir - descobrir tudo, enraivecer, ficar louco, assassiná-los -, comprova tão somente, com sua morna recepção, a palidez cotidiana daquele romance espúrio, tão logo decaído e adaptado à sociedade sensaborão. Descobrem os amantes que têm, como todos hão de ter, a vida gelada; do amor pretensamente épico, restara o beijo do defunto, ao qual certo sabor cáustico poderia socorrer. No próximo capítulo, o pessimismo de Brás Cubas intervém novamente e debocha do leitor, que gostaria de encontrar qualquer outra coisa nesse beijo:

meramente "sensacional". Se comparado com um romance convencional, não há nenhum evento que, segundo a terminologia estrangeira, possa servir de spoiler das Memórias; isto é, aquele trecho da narrativa que, caso seja contado ao leitor antes que este atinja a última página, estraga significativamente sua experiência emotiva de leitura. Isto devese, conforme será discutido mais a frente, ao fato de que não há nada que intervenha no livro para acudir à perplexidade da narrativa um sentido de vida mais profundo, duradouro e inenarrável.

eISSN: 2179-8478

DOI: $10.17851 / 2179-8478.11 .123-176$ 


\section{CAPÍTULO XCVII / ENTRE A BOCA E A TESTA}

Sinto que o leitor estremeceu, - ou devia estremecer. Naturalmente a última palavra sugeriu-lhe três ou quatro reflexões. Veja bem o quadro: numa casinha da Gamboa, duas pessoas que se amam há muito tempo, uma inclinada para a outra, a dar-lhe um beijo na testa, e a outra a recuar, como se sentisse o contato de uma boca de cadáver. Há aí, no breve intervalo, entre a boca e a testa, antes do beijo e depois do beijo, há aí largo espaço para muita coisa, - a contração de um ressentimento, - a ruga da desconfiança, - ou enfim o nariz pálido e sonolento da saciedade... (p.100, grifo do autor)

Onde deveriam haver sangue, desespero e terror, quem sabe fuga e a volta do sabor cáustico de um verdadeiro romance, há apenas a insinuação do verme carcomendo o homem, já cansado, enfermo, pálido, sonolento ou enfim defunto, sob efeito do trespasse do enxurro perpétuo da vida. Ou seja, o beijo do defunto como pálido e sonolento lugarcomum.

\section{Edição Definitiva, Exemplar Único, Coisa Nenhuma}

Com a noção geologia ${ }^{9}$ da moral temos, com efeito, uma completa inversão do que viemos discutindo até o momento. Da ênfase nas reminiscências, nas sensações e na ébria tessitura de correspondências desse exemplar único, passa-se alhures ao domínio mais próximo àquele da edição definitiva, isto é, da imagem integral e fundamental do caráter do homem.

\footnotetext{
${ }^{9}$ Roberto Schwarz está correto em analisar a relação da obra com a ciência do século XVIII e XIX, em especial, o positivismo e o naturalismo de Darwin. Entretanto, discordamos quando este atribui certa inconsistência nas referencias cotejando com o conteúdo específico que veiculam. Nossa opinião é de que, mais do que aspecto específico, elas aparecem no romance a título de representantes da "ciência da vida, que não teve necessidade de sacrificar a racionalidade para manter, no mais vivo de sua consciência, a especificidade do ser vivo e esse calor um pouco subterrâneo que circula entre ele — objeto de nosso conhecimento — e nós, que estamos aí para conhecê-lo." (FOUCAULT, 2000, p.335)
}

eISSN: 2179-8478

DOI: $10.17851 / 2179-8478.11 .123-176$ 
Com efeito, há diversas teorias ao longo do romance que relembram, em teor e inconsistência, a ideia de uma geologia da moral. A filosofia ébria de Brás Cubas é pródiga em criá-las. Entretanto, ao evitar aprofundar tal geologia da moral, sob risco de interromper a narrativa, Brás Cubas reforça a incompatibilidade de toda ideia definitiva e integral com a tessitura reminiscente do gênero romanesco, incapaz de repercutir qualquer sentido para além do meramente sensacional. Dessarte, a mais significativa de todas as teses da filosofia de Brás Cubas (na qual culminam tantas outras, entre elas, a do enxurro perpétuo da vida) será, justamente, aquela que não poderá ser contada para que não se interfira na narrativa - a qual, notadamente, já havia sofrido todo tipo de interferência à esta altura.

Um dos aspectos mais cruciais da composição de Memórias Póstumas de Brás Cubas consiste em como determina (e eventualmente extrapola) os limites e convenções que crê ter a narração. Já mencionamos alguns até aqui, como a geologia da moral e aquele bilhete acerca do qual seria melhor que nada mais tivesse sido dito; mas há diversos outros ${ }^{10}$.

Logo no início do livro, quando ainda discute a possível causa mortis de si - a ideia fixa de criar um emplasto anti-hipocondríaco - logo adverte o leitor: "não esteja daí a torcer-me o nariz, só porque ainda não chegamos à parte narrativa destas memórias." (p.5). Nesse esteio, podemos dizer que todo o trecho que antecede a "narrativa" propriamente dita - que começará com seu nascimento - é uma espécie de arco prénarrativo. O mesmo acontece com o final do romance, que são na verdade dois: um literal, a última página; e outro sugerido, exclusivo da narração: "E agora sinto que, se

\footnotetext{
${ }^{10}$ Enumeramos alguns: 1) no capítulo "CXXVI - Desconsolação", logo após a transcrição de um epitáfio, comenta Brás Cubas: "O epitáfio diz tudo. Vale mais do que se lhes narrasse a moléstia de Nhã-loló, a morte, o desespero da família, o enterro"(p.119). 2) No capítulo "XLV - Notas", Brás Cubas transcreve todo um inventário de objetos e gestos acerca do funerário de seu pai e que, entretanto, não passariam de notas para um "capitulo triste e vulgar que não escrevo" (p.53). 3) Além disso, há toda sorte de momentos em que Cubas debocha de convenções literárias e seus efeitos no leitor - por exemplo: "Não se irrite o leitor com esta confissão. Eu bem sei que, para titilar-lhe os nervos da fantasia, devia padecer um grande desespero, derramar algumas lágrimas, e não almoçar. Seria romanesco; mas não seria biográfico.” (p.111, grifo do autor).
}

eISSN: 2179-8478

DOI: $10.17851 / 2179-8478.11 .123-176$ 
alguma dama tem seguido estas páginas, fecha o livro e não lê as restantes. Para ela extinguiu-se o interesse da minha vida, que era o amor.” (p.124).

Outro limite convencional - este constantemente desrespeitado - é o próprio leitor, que exigiria de Cubas que permaneça no interior da narração. Como neste capítulo:

CAPÍTULO LXXI / O SENÃO DO LIVRO

Começo a arrepender-me deste livro. Não que ele me canse; eu não tenho que fazer; e, realmente, expedir alguns magros capítulos para esse mundo sempre é tarefa que distrai um pouco da eternidade. Mas o livro é enfadonho, cheira a sepulcro, traz certa contração cadavérica; vício grave, e aliás ínfimo, porque o maior defeito deste livro és tu, leitor. Tu tens pressa de envelhecer, e o livro anda devagar; tu amas a narração direta e nutrida, o estilo regular e fluente, e este livro e o meu estilo são como os ébrios (...) (p.78, grifo do autor).

A narração é comprimida em seu limite por certa contração cadavérica. Essa contração se deveria à natureza póstuma do livro, em última instância, o fato de que o único elemento que interliga a narração ao mundo real trata-se, conforme já notara Roberto Schwarz, de um inverossímil: sua própria condição de defunto. Não há nada que pressione o narrador a andar mais rápido, já que não tem a vida breve. A vida - seja ela épica, seja ela vida dos corpos - não nutre de forma alguma a narração, que cheira a sepulcro. O estilo ébrio da narrativa, tomada por sensações muitas vezes baratas, em todo caso, densamente confusas, indistinguíveis, é senão efeito da própria reminiscência, a única matéria que restara ao defunto. São as reminiscências - episódicas e confusas, desligadas do enxurro da vida e ansiosas por um sentido que nunca vem - que pendem como folhas misérrimas do cipreste da narração sob efeito do vento saudoso.

Outro limiar dessa contração cadavérica consiste na opção por narrar a própria morte logo no introito do romance - coisa que sequer Moisés, que também narrara a própria morte, fizera (e que está no arco que chamamos de "pré-narrativo"). O que seria resguardado geralmente para o fim do romance - em geral, sob título de se confirmar o que na vida fora seu verdadeiro destino épico - fora substituído por um capítulo repleto de negativas que não tem outro intuito senão de desestimular o leitor em refletir sobre o

eISSN: $2179-8478$

DOI: $10.17851 / 2179-8478.11 .123-176$ 
sentido da vida. O único saldo positivo da vida de Brás Cubas é, segundo a derradeira linha do romance, o fato de não ter tido filhos e não ter transmitido "a nenhuma criatura o legado da nossa miséria” (p.140).

Por fim, outro limite convencional é aquela evocada no capítulo "O Delírio" - no qual Cubas se encontra com a monstruosa e inapreensível figura personificada da Natureza. Narrar o próprio delírio, diz Cubas, tem valor meramente de curiosidade para os anais da ciência; e sugere que, caso o leitor não for "dado à contemplação destes fenômenos mentais, pode saltar o capítulo; vá direito à narração.” (p.8). Embora essa convenção (interesse científico) não seja, propriamente, romanesca; é utilizada para situar o delírio fora da narração e, sobretudo, para desqualificá-lo. Como se o delírio fosse, em si, menos crível que sua própria condição de defunto. Deparamo-nos desse modo com o indício de que todo este trecho que envolve a Natureza é o verdadeiro elemento estranho na narrativa de Brás Cubas, incompossível com seu romance.

Para analisarmos, entretanto, de como são tecidas e perturbadas as relações para além dos limites e convenções do gênero romanesco, será necessário fazer recurso direto àquilo que, até o momento, servira de alicerce oculto deste ensaio, as reflexões de Walter Benjamin acerca do romancista e do narrador.

\section{0 romancista}

\subsection{Estágio de indiferenciação}

Em "O Narrador - Considerações Sobre a Obra de Nikolai Leskov", Walter Benjamin discute a crise da narrativa oral na sociedade moderna, bem como a

eISSN: $2179-8478$

DOI: $10.17851 / 2179-8478.11 .123-176$ 
predominância do gênero romanesco - melhor adaptado à imprensa e à sociedade burguesa - não como fenômenos isolados e autônomos, mas interligados e em tensão dialética.

Para Benjamin, tanto o romance quanto a narrativa teriam mesma origem: a epopeia, cuja musa épica seria a rememoração (Erinnerung). $\mathrm{Na}$ epopeia, o romance e a narrativa estariam em um estágio de indiferenciação. Com o passar do tempo, se distanciariam do elo da rememoração: a musa da narrativa tornar-se-ia a memória épica (Gedachtnis); a do romance, reminiscência (Eingedenken) ${ }^{11}$.

(...) ela [a musa do romance] já pode ser pressentida na poesia épica. Acima de tudo nas invocações solenes das Musas, que abrem os poemas homéricos. O que se anuncia nessas passagens é a memória perpetuadora do romancista, em contraste com a breve memória do narrador. A primeira é consagrada a um herói, uma peregrinação, um combate; a segunda, a muitos fatos dispersos. Em outras palavras, a reminiscência (Eingedenken), musa do romance, surge ao lado da memória (Gedachtnis), musa da narrativa, depois que a desagregação da poesia épica apagou a unidade de sua origem comum na rememoração (Erinnerung). (p.228)

A rememoração fundamentaria a longa cadeia da tradição transmitida de geração a geração. Seria, por excelência, elaborada pela narrativa oral, com seu modo artesanal e compartilhado de tecer uma história mediante o labor de diversas mãos e de interligar várias histórias entre si. A narrativa oral conserva suas histórias sobretudo por estas serem passíveis de, logo após serem ouvidas, serem novamente recontadas por aquele que a escutara com tal intimidade como se dele experiência fosse. $\mathrm{Na}$ epopeia, alimentada sobretudo pelas narrativas orais, poder-se-ia pressentir ainda a musa perpetuadora do romance. $^{12}$

\footnotetext{
${ }^{11}$ BENJAMIN, 2012, p.228. Importante destacar que utilizamos a versão revisada e atual de Sérgio Paulo Rouanet. Em outras edições, ele havia optado por inverter os termos. Onde, na versão atual, lê-se rememoração, lia-se reminiscência e vice-versa.

${ }^{12}$ Benjamin cita as invocações solene das musas, como esta, colhida da Ilíada: "Dizei agora a mim, Musas que a olímpica morada tendes, / pois vós sois deusas, presentes estais e tudo sabeis - / enquanto nós a fama apenas ouvimos, nada sabemos - / quem os chefes dos dânaos e seus condutores eram." (HOMERO cit. por BRANDÃO, 2015, p.40, grifo do autor). Sem adentrarmos nas complexas relações do poeta com as musas em Homero; bastaria pressentir, tão
}

eISSN: 2179-8478

DOI: $10.17851 / 2179-8478.11 .123-176$ 
Entretanto, à medida que o romance se desenvolve e passa para o primeiro plano da literatura, sobretudo à partir do advento da burguesia e da invenção da imprensa, ocorreria uma espécie de descolamento dessa memória perpetuadora no interior da rememoração - podendo distinguir-se desse modo uma musa memória épica e outra, da reminiscência.

\subsection{História natural}

A musa da narrativa, memória épica, teria "breve memória" (BENJAMIN, 2012, p.228); o modo de relatar a experiência buscaria chegar à estrutura mais simples possível: onde o miraculoso e extraordinário é narrado com precisão e o contexto psicológico da ação não é imposto ao ouvinte. $\mathrm{O}$ ato de narrar se furtaria da análise psicológica e implicaria, de certo modo, um ato de refinamento - espelhado em "coisas perfeitas que se encontram na natureza - pérolas imaculadas, vinhos encorpados e maduros, criaturas realmente perfeitas (...) 'o produto precioso de uma longa cadeia de causa semelhantes entre si"'(p.222). Refino prolongado no tempo, cristais sob efeito da pressão da eternidade.

Na narrativa se entrelaçariam duas figuras arquetípicas do narrador: o marinheiro e o camponês; emaranhado o desconhecido, a vastidão do mar, com o cotidiano profundo, traçado sobre a terra repisada; emaranhado o homem, em afinidade com o natural, a eternidade de longas beiras; de toda narrativa emergiria uma espécie de "moral da história", ou melhor, de senso prático:

[a narrativa] traz sempre consigo, de forma aberta ou latente, uma utilidade.

somente, a necessidade de que se interfira o perpétuo na fama que corre à boca dos homens, pois somente sabem o que ouviram dizer.

eISSN: $2179-8478$

DOI: $10.17851 / 2179-8478.11 .123-176$ 
Essa utilidade pode consistir por vezes num ensinamento moral, ou numa sugestão prática, ou também num provérbio ou norma de vida - de qualquer maneira, o narrador é um homem que sabe dar conselhos ao ouvinte. (BENJAMIN, 2012, p.216)

O tédio, a monotonia - que são o ponto alto da distensão do espírito; assim como o sono é a distensão do corpo - é o pássaro que choca os ovos da narrativa. Para Benjamin toda narrativa - emanada da terra e do mar; afim aos ritmos lentos da natureza; recriada através de uma tessitura anônima sem fim; e conservada próxima ao cotidiano, que lhe sagraria finalidade épica, o sábio conselho, ao ato de recordar - remeteria à história natural. A sabedoria de toda narrativa derivaria da morte. Do moribundo emanaria a autoridade e a transmissibilidade da experiência (diferentemente daqueles boquiabertos de olhares indecifráveis e expirantes que permeiam as Memórias Póstumas de Brás Cubas):

Ora, é no moribundo que não apenas o saber e a sabedoria do homem, mas sobretudo sua vida vivida - e é dessa substância que são feitas as histórias assumem pela primeira vez uma forma transmissível. Assim como no interior do agonizante desfilam inúmeras imagens - visões de si mesmo, nas quais ele havia se encontrado sem dar-se conta disso -, o inesquecível aflora de repente também em suas expressões e olhares, conferindo a tudo o que lhe dizia respeito aquela autoridade que mesmo um pobre-diabo possui, ao morrer, para os vivos em seu redor. Na origem da narrativa está essa autoridade. (p.224, grifo do autor)

Nos moribundos do romance de Brás Cubas jamais aflora qualquer imagem gratuita, imprevisível e transmissível da vida vivida. Nem a macilenta Marcela, tampouco o convalescente pai e, muito menos, a escandalizada Virgília veem despontar do moribundo qualquer outra coisa, senão algo de inacreditável ou indecifrável, uma espécie de "concentração de luz" que, não sendo o suficiente para confirmar a verdadeira causa daquela morte - a cobiça, a sede por status quo, o adultério -, não serve também para negá-la; permanecendo desse modo a vida vivida apenas pressuposta, portanto inenarrável, pelo rumor da causa mortis. E, conforme discutiremos a seguir, tampouco vira Cubas, em seu último delírio anterior à morte, o inesquecível aflorado diretamente de

eISSN: $2179-8478$

DOI: $10.17851 / 2179-8478.11 .123-176$ 
sua vida; pelo contrário, o que vira fora, supostamente, o que veria o gavião Buffon... É da morte, a regularidade com que a morte ocorre naturalmente no espaço e no tempo, que se extrairia o novelo do qual se teceriam tal história natural:

Hoje, os burgueses, inquilinos de primeira hora da eternidade, vivem em espaços depurados da morte e, quando chegar sua hora, serão depositados por seus herdeiros em sanatórios e hospitais. Ora, é no moribundo que não apenas o saber e a sabedoria do homem, mas sobretudo sua vida vivida - e é dessa substância que são feitas as histórias - assumem pela primeira vez uma forma transmissível. Assim como no interior do agonizante desfilam inúmeras imagens - visões de si mesmo, nas quais ele havia se encontrado sem dar-se conta disso -, o inesquecível aflora de repente também em suas expressões e olhares, conferindo a tudo o que lhe dizia respeito aquela autoridade que mesmo um pobre-diabo possui, ao morrer, para os vivos ao seu redor. Na origem da narrativa está essa autoridade.

(...) A morte é sanção de tudo o que o narrador pode relatar. É da morte que ele deriva sua autoridade. Em outras palavras: suas histórias remetem à história natural. (p.224)

Na narrativa oral, essa espécie de enxurro da morte reforça o senso de cadência da vida; a morte não confronta a vida, ela sela sua mágica perenidade; confere-lhe o ritmo natural do cruzamento do dia e da noite; às vezes, dá de dançar. O narrador está ligado às fábulas e aos contos de fada.

Uma escada que chega até o centro da terra e que se perde nas nuvens - é a imagem de uma experiência coletiva, para a qual mesmo o mais profundo choque da experiência individual, a morte, não representa nem um escândalo nem um impedimento. "E se não morreram, vivem até hoje", diz o conto de fadas." (p.232)

\subsection{Vida gelada}

Benjamin transcreve o fim do romance A Educação Sentimental, de Gustave Flaubert, para tratar do rigor com o gênero impõe, para si, a última palavra:

eISSN: $2179-8478$

DOI: $10.17851 / 2179-8478.11 .123-176$ 
"Falava-se ainda dessa história três anos depois. E agora eles a contavam extensivamente, um completando as recordações do outro. 'Foi, talvez', disse Frédéric, quando haviam terminado, 'o momento mais belo de nossas vidas.' 'Sim, é capaz que tenhas razão', disse Desaurires. 'O mais belo de nossas vidas"” (FLAUBERT cit. por: BENJAMIN, 2012, p.230)

A palavra FIM, escrita preferencialmente em versalete no canto inferior da última página, seria o limite último para além do qual aquela história não poderá dar um único passo além. Sendo assim, o FIM selaria o convite para que o leitor reflita solitariamente acerca do sentido da vida. O fim inequívoco do romance seria, desse modo, uma das faces da morte: "foi, talvez (...) o mais belo de nossas vidas".

Para Benjamin, o romance se relacionaria de modo distinto com a morte e a rememoração. Se, por um lado, todo narrador teria na "breve memória" (BENJAMIN, 2012, p.228) a justa medida da semente que germina na alma daquele que ouve; ao romancista nada satisfaria senão perpetuar os fatos episódicos da reminiscência em uma espécie de plenitude:

O romancista segrega-se. A origem do romance é o indivíduo isolado (...) Escrever um romance significa, na descrição da vida humana, levar o incomensurável a seus últimos limites. Em meio à plenitude dessa vida e na descrição dessa plenitude, o romance anuncia a profunda perplexidade de quem a vive. (p.217)

Tal perplexidade se anunciaria, sobretudo, como efeito da cisão entre sentido e vida. Na narrativa oral, o saber adviria de longe e disporia "de uma autoridade que lhe conferia validade, mesmo que não fosse subsumível ao controle" (p.219). No romance, porém, a experiência vivida pela personagem não lhe outorgaria saber algum, senão, a perplexidade, eventualmente convertida numa espécie de apreensão divinatória e intuitiva do sentido, conforme Lukács, citado por Benjamin:

Somente o romance... separa o sentido e a vida, e, com isso, o essencial e o temporal; podemos quase dizer que toda a ação interna do romance não é senão a luta contra o poder do tempo... E desse combate... emergem as vivencias temporais autenticamente épicas: a esperança e a rememoração... Somente no

eISSN: $2179-8478$

DOI: $10.17851 / 2179-8478.11 .123-176$ 
romance... ocorre uma rememoração criadora, que atinge seu objeto e o transforma... O sujeito só pode ultrapassar o dualismo da interioridade e exterioridade quando percebe... a unidade de toda sua vida... na corrente vital do seu passado, comprimida na rememoração... A visão capaz de perceber essa unidade é a apreensão divinatória e intuitiva do sentido da vida, inatingido e, portanto, inexprimível. (LUKÁCS, cit. por BENJAMIN, 2012, p.229)

Seria função do romancista criar os momentos em que tal apreensão intuitiva do sentido entrecorta a perplexidade, tornando-a legível para o leitor. Dito de outro modo, segundo Benjamin, o romance deve ser capaz de anunciar ao leitor de antemão que a morte espera as personagens; e o grande prazer de ler consistiria, justamente, em entrever estes indícios. Se, na narrativa, a morte ecoaria os ritmos naturais e prolongados da vida na terra; no romance, ela figuraria como o abalo último que torna subitamente legível o "puro em si da coisa narrada" (p.221): o sentido hipostasiado através da apreensão divinatória. Sendo a morte a síntese última entre sentido e vida; a cumplicidade do leitor como romance consistiria em querer participar da morte da personagem - seja ela morte figurada, o "fim do romance"; mas de preferencia morte verdadeira (p.231).

"Com efeito, não há nenhuma narrativa em que a pergunta - e o que aconteceu depois? - não se justifique. O romance, ao contrário, não pode dar um único passo além daquele limite em que, escrevendo na parte inferior da página a palavra fim, convida o leitor a refletir sobre o sentido da vida" (p.230)

Esta seria, portanto, a importância do objeto livro para a cultura romanesca. Sem a possibilidade de perpetuar, para uma determinada história, um rigoroso e irretorquível fim, não poderia haver a chama que alimenta o romance: a cisão entre sentido e vida - e a possibilidade de reconciliação sob efeito da morte na reminiscência, perpetuada na página do romance. Benjamin destaca a frase de Moritz Heimann, que diz: "Um homem que morre com trinta e cinco anos é em cada momento de sua vida um homem que morre com trinta e cinco anos" (p.231). Segundo o autor, o que na frase seria um contrassenso do ponto de vista da vida real, é incontestável sob a ótica das reminiscências: “"o sentido’ de sua vida somente se revela a partir de sua morte" (p.231).

eISSN: $2179-8478$

DOI: $10.17851 / 2179-8478.11 .123-176$ 
Dessarte o estatuto histórico completamente distinto da narrativa e do romance e seus respectivos fins, a "moral da história" e o "sentido da vida" (p.230). O que, acolá, acolheria certa cadência ao conceber uma continuidade da história e do saber que engendra; aqui, assume a forma perpétua e inequívoca da revelação do sentido. E a relação com a revelação, oportunizada, sobretudo, pela morte, é completamente outra. Benjamin descreve, em contraposição ao evento público da convalescença de outrora, o espaço absolutamente depurado de morte da sociedade burguesa - confinadas em sanatórios e hospitais ${ }^{13}$ (p.224). Logo após, porém, reposiciona a morte no núcleo ardente da trama romanesca em uma série de imagens corpóreas do livro que em muito espelham essa espécie de transubstanciação de Brás Cubas no livro-corpo que deve ser roído. Para o filósofo, todo leitor burguês solitariamente tomaria um livro de romance em suas mãos para apoderar-se, alimentar-se de sua matéria:

[O leitor] Quer apropriar-se dela, devorá-la, de certo modo. Sim, ele destrói a substância lida, como o fogo devora a lenha na lareira. A tensão que atravessa o romance se assemelha muito à corrente de ar que alimenta e reanima a chama. $\mathrm{O}$ interesse ardente do leitor se nutre de um material seco (p.230-231).

Pois é o leitor, sobretudo, quem padece da absoluta falta de sentido em sua vida. Por isso quer ter certeza de que irá participar da morte de homens nas quais se possam ler "o sentido da vida" - morte, seja no sentido figurado, fim do romance, ou, preferencialmente, no sentido verdadeiro e literal (p.231).

Ou seja, o romance não é significativo por descrever pedagogicamente um destino alheio, mas porque esse destino alheio, graças à chama que o consome, pode nos fornecer o calor que não podemos encontrar em nosso próprio destino. $\mathrm{O}$ que atrai o leitor ao romance é a esperança de aquecer sua vida gelada com a morte descrita no livro. (p.231, grifo do autor) ${ }^{13}$ Não surpreende, desse modo, que Cubas tenha pretendido descrever seu delírio fúnebre com vistas "apenas" a
entesourar a literatura médica.

eISSN: 2179-8478

DOI: $10.17851 / 2179-8478.11 .123-176$ 
Fundamental para Benjamin, portanto, será essa espécie de relação carnal entre o leitor burguês e o sentido da vida, subitamente revelado através da convergência de chamas ardentes que trespassam a narrativa para culminarem na morte.

\section{Musa cativa}

A partir da leitura de Walter Benjamin, podemos inferir algumas características da estrutura do romance de Machado de Assis.

Primeiro, que a grande novidade de Memórias Póstumas de Brás Cubas não fora apenas a escrita de perspectiva póstuma. Fora igualmente importante a opção de narrar a morte do protagonista logo no introito; e fazê-lo dar seu ponto de vista indiferente: de que não passara de um evento tranquilo e metódico - "a orquestra da morte foi muito menos triste do que podia parecer. De certo ponto em diante chegou a ser deliciosa." (p.140). A morte não servira como ponto de inflexão da perplexidade que Brás Cubas sentira quando vivo. As reminiscências prolongam a perplexidade; e a eternidade póstuma não oportunizara muito mais que a tessitura de sensações correspondentes. A opção de narrar a morte no introito invertera abruptamente todo efeito que, para Benjamin, cumpriria à musa da reminiscência alimentar no gênero romanesco: a consumação da perplexidade na chama ardente da vida à qual a morte (e o fim do romance), encantada pela musa da reminiscência, reconciliará o sentido ulterior, "o mais belo de nossas vidas". Para Brás Cubas, a morte não é apenas um evento metódico e indiferente, como um outro qualquer; a morte não lhe fizera sentido algum da vida. Suas memórias carecem, doravante, desse ponto convergente e decisivo do sentido com a vida; significa dizer: suas memórias estão privadas de progredirem, sem tropeço, até o verdadeiro fïm do romance.

eISSN: $2179-8478$

DOI: $10.17851 / 2179-8478.11 .123-176$ 
Antes, cumpre elaborar um breve comentário acerca da crítica à apologia do autor, que fizemos no início deste artigo. Com efeito, não se trata de eliminar da análise literária o autor; tampouco reduzi-lo ao artifício cultural e sociológico. Trata-se de atribuir ao autor somente aquilo que o narrador, a trama e suas personagens não puderem assimilar. O autor está, justamente, nos eventuais pontos cegos que a trama esconde para si mesma. E Brás Cubas não pode compreender por que a morte não lhe fizera sentido algum da vida; e tampouco pode confrontar, no espaço do romance, essa deficiência. Continuara, após sua morte, um burguês; ficara a meio caminho do verdadeiro romance: se é saudoso, pessimista e rabugento; se seu grande amor não passara, enfim, de um sobressalto inconsistente e sensaborão; nada disso impede que sonhe, ainda, com a nomeada. Tal qual fizera com seu emplasto, dera seu nome ao romance - Memórias Póstumas de Brás Cubas. E, a exemplo de seu emplasto, sabe ser um tanto tolo esperar de um produto homeopático a glória; todavia, escreve-o. E é essa conjunção - todavia - que devemos atribuir a Machado de Assis: o romance e a burguesa corroem-se um ao outro, na expectativa de que um venha suprir a lacuna que naquele falta. Se, em Flaubert, ao fim do romance acode a beleza, que subitamente trespassa as reminiscências; para Brás Cubas, o fim do romance não passa de um capítulo de negativas ao qual nada poderá socorrer. Desse modo, Machado trama para Brás Cubas reduplicado carcomer: suas reminiscências, a exemplo do que acontecera com seu corpo, descerão à imobilidade objetiva do livro, e a narrativa fazer-se-á ébria, e sensacional e garatujada, e coisa nenhuma.

Esse abalo - o confrontamento com a morte que jamais fará sentido algum da vida - corrói o canto da musa da reminiscência. Às Memórias de Brás Cubas não acodem aquilo que, segundo Benjamin, seria função do romance: anunciar que a morte espreita a personagem, prenunciando o verdadeiro sentido da vida, inenarrável. Há, com efeito, uma porção de situações que poderiam assumir tal função; entretanto, à medida que nenhuma chama as atravessa, Brás Cubas torna-se um charlatão: sabe que ludibria o leitor e

eISSN: $2179-8478$

DOI: $10.17851 / 2179-8478.11 .123-176$ 
debocha de seu interesse. Ao leitor - à quem, segundo Benjamin, interessaria devorar o romance em busca da chama que aqueceria sua vida gelada - restara pouco; assim como restará pouco de sua vida gelada. Se Benjamin falara de certa melancolia que abate o romancista ao receber a parca herança de reminiscências do morto; aqui, resta a dura lição de que nos converter em romancistas é inútil, se esperarmos com isso extrair algo mais dessa parca soma que levaremos da vida quando morrermos. Compreende-se enfim para que servem, de fato, as reminiscências: não para elaborar o inapreensível sentido da vida; mas para estimular o livre exercício desse capricho despótico que consiste em, através de metáforas delicadas e transparentes, vender e comprar a vida a preços baratos.

$\mathrm{O}$ romance repercute na sua estrutura o efeito da musa em cativeiro. Tudo aquilo que, em um romance convencional, serviria para atiçar no leitor a expectativa pelo sentido da vida é exposto em sua crua maquinaria. Não passam de sensações extremamente confusas, quando não francamente baratas; lugares-comum que poderiam dizer o que qualquer um quiser que deles se diga. Sensações, isto é, algo menos que palavras: diacríticos ásperos, rabiscos sem intenções alfabéticas, garatujas, anedotas despropositadas - papéis de toda sorte, confirmando a degenerescência da narração. E as reminiscências não podem fazer muito mais que elaborar correspondências de sensações enquanto assiste, passivamente, a ação do verme insinuar-se sobre aquele corpo desde cedo convertido em melancólico hipocondríaco. O canto da musa, gaguejando entremeio a garatujas e eventos insignificantes, não é capaz de algo mais que sensações; seu efeito "sensacional" equivale a lugares-comuns que coincidem com o destino somente por puro acaso, virumque vir; sob a perspectiva reminiscente, valem somente para uma tessitura de correspondências - que são a forma degenerada, carcomida, do sentido da vida. Em resumo, tudo aquilo que, sob a benção da musa, serviria para perpetuar como sintoma o épico, o trágico, para convulsionar a chama ardente; servirá, aqui, apenas para carcomer o próprio romance. Romance que, sem poder simular ser uma edição definitiva, esforça-se em vão para torna-se ao menos um exemplar único.

eISSN: 2179-8478

DOI: $10.17851 / 2179-8478.11 .123-176$ 
Dessarte, o romance todo padece de uma contração cadavérica que torna cativa sua musa da reminiscência e todo seu poder evocativo do tempo da vida épica. O leitor, que tem pressa de envelhecer, é o primeiro alijado desse sistema fechado do romance que encarcerara sua musa. O sistema é fechado sob vários aspectos: trata-se de um único exemplar de objeto-livro; é escrito por um defunto autor, privado de todo contato com o mundo exterior; as folhas decaem exclusivamente do abstrato despropósito; o fim não acolhe nenhum sentido ulterior, tampouco convida a refletir sobre o sentido da vida; e as reminiscências, por sua vez, são meros modos de estabelecer uma correspondência de sensações às quais podem ser lidas como quiser. Ler o romance é, senão, sentir o beijo do defunto: essa espécie de compaixão indiferente que emana daquele que tem certeza de que não houve, nem poderá haver, o "mais belo de nossas vidas". O fim do romance, composto exclusivamente de negativas, previne-se de qualquer abertura e estabelece, categoricamente: o único saldo positivo daquela vida fora não ter transmitido o legado da miséria a nenhuma outra criatura; depreende-se: o que está perpetuado nessas páginas permanecerá circunscrito ao limite arbitrário do objeto-livro, ao qual nenhum sibilar da musa poderá animar.

\section{Eternamente hipocondríacos pela voluptuosidade do nada}

Memórias Póstumas de Brás Cubas é um romance? - já desconfiava Brás Cubas que sim e que não. Sistema fechado, carcomendo a si. Brás Cubas não pode compreender o abalo do sem-sentido da morte; mas, de algum modo, desconfia: não passamos de sujeitos eternamente hipocondríacos.

Desconfia de que a hipocondria desabrochara ainda jovem, sob insinuação dos grandes livros:

eISSN: $2179-8478$

DOI: $10.17851 / 2179-8478.11 .123-176$ 
Renunciei tudo; tinha o espírito atônito. Creio que por então é que começou a desabotoar em mim a hipocondria, essa flor amarela, solitária e mórbida, de um cheiro inebriante e sutil. - "Que bom que é estar triste e não dizer coisa nenhuma!" - Quando esta palavra de Shakespeare me chamou a atenção, confesso que senti em mim um eco, um eco delicioso. Lembra-me que estava sentado, debaixo de um tamarineiro, com o livro do poeta aberto nas mãos, e o espírito ainda mais cabisbaixo do que a figura, - ou jururu, como dizemos das galinhas tristes. (p.36)

Mas fora certa ideia fixa que, anos mais tarde, atravessaria seu trapézio, que fizera com que a flor mórbida se recolhesse "ao botão para deixar a outra flor menos amarela, e nada mórbida, - o amor da nomeada, o emplasto Brás Cubas.” (p.40). O Emplasto Brás Cubas é, nada menos, que um emplasto anti-hipocondríaco que curaria toda a melancólica humanidade. Está completamente tomado pela ideia fixa, que lhe repercutia sonhos de toda sorte na qual contemplava os benefícios pessoais do emplasto: tornar-se filantropo; possuidor de faustosa herança; aparecer nas capas de jornais; em resumo, "ascender do chão das turbas, e remontar ao Céu, como uma águia imortal" (p.6). Eis que, de repente, uma lufada de ar, com toda sua frialdade inorgânica, lhe golpeia e lhe põe doente. Tomado pela ideia fixa, não percebe bem a insinuação da doença, não se trata: e morre. O emplasto sendo assim a verdadeira causa - o caso (e não acaso) - de sua morte:

Entre a morte do Quincas Borba e a minha, mediaram os sucessos narrados na primeira parte do livro. O principal deles foi a invenção do emplasto Brás Cubas, que morreu comigo, por causa da moléstia que apanhei. Divino emplasto, tu me darias o primeiro lugar entre os homens, acima da ciência e da riqueza, porque eras a genuína e direta inspiração do Céu. $O$ caso determinou o contrário; e aí vos ficais eternamente hipocondríacos. (p.140, grifos do autor).

Uma similar ideia fixa trespassa o romance póstumo: é o próprio ato de escrevêlo. Cultiva a ilusão de ser bem quisto pelo leitor. Sabe, entretanto, que não passa de uma ilusão: a chama de seu romance com Virgília não passando de um mero efeito homeopático do emplasto que jamais surtirá efeito alhures a este leitor que tem pressa de envelhecer e, portanto, requer nada menos que a chama ardente romanesca capaz de

eISSN: $2179-8478$

DOI: $10.17851 / 2179-8478.11 .123-176$ 
aquecer sua vida gelada. O leitor prefere a narração direta e nutrida; mas Brás Cubas só pode oferecer-lhe beijos de defunto, como quem diz (ecoando a voz da Natureza): leitor, "grande lascivo, espera-te a voluptuosidade do nada." (p.11).

Segundo seu biógrafo, Vicente Valero, Walter Benjamin pretendia incluir em seu ensaio "O Narrador" um trecho acerca dos supostos efeitos curativos de se narrar uma história ao enfermo. Teria se inspirado nas falas de seu amigo Felix Noeggerath que, enfermo, lhe descrevera desse modo os poderes das mãos de sua mulher, Marietta: "Sus movimentos son muy expressivos. Pero resulta impossibile describir su expression.... Es como si estuvieran contando un cuento" (VALERO, 2001, p.44-45). Supõe-se que a morte de Noeggerath, um forte abalo para Benjamin, teria sido a causa deste trecho ter sido subtraído do ensaio; todavia, reaparece mais tarde nas "Imagens do Pensamento", no trecho "Conto e Cura". Benjamin associa a cura à situação na qual a mãe, sentada ao lado da criança enferma, passa horas a fio contando-lhe histórias. Benjamin indaga-se:

(...)Daí vem a pergunta se a narração não formaria o clima propício e a condição mais favorável de muitas curas, e mesmo se não seriam todas as doenças curáveis se apenas se deixassem flutuar para bem longe - até a foz - na correnteza da narração (BENJAMIN, 1987, p,267)

A partir das Memórias, podemos nos indagar se não ocorreria para o romance uma fórmula inversa. Não seria o romance o formador de uma condição favorável para a morte; e ainda, não seriam todas as doenças fatais se apenas se deixassem levar para bem longe - até a ideia fixa (épica) - no enxurro do romance? Não seria o romance, assim como o emplasto, algo que diz ser capaz de curar toda a melancolia das vidas geladas com o benefício da chama ardente do sentido da vida; mas que, em contrapartida, serviria apenas para fazer desabrochar a flor amarela da hipocondria ao inspirar-nos a sede de nomeada, a ideia fixa, a pressa de envelhecer, em sua, a voluptuosidade do nada?

eISSN: $2179-8478$

DOI: $10.17851 / 2179-8478.11 .123-176$ 


\section{Outro flagelo}

Dissemos que Memórias é um sistema fechado, carcomendo a si próprio. Seria possível consumir o romance a si próprio por seus próprios meios? Ou ainda, será necessário que outra força extrínseca intervenha para que a musa da reminiscência tornese cativa de seu próprio canto?

Com efeito, Machado de Assis, ao pretender escrever sob perspectiva póstuma à qual a morte pouco importara como evento significativo, tivera de solucionar de algum modo o mistério sem o qual a musa da reminiscência jamais poderia sibilar seus segredos: as parcas reminiscências que eventualmente nos acometeriam o breve instante que antecede a morte.

Trata-se, certamente, de um lugar-comum do romance a ideia de que as experiências imediatamente anteriores à morte são, necessariamente, experiências súbitas de reminiscência da própria vida ${ }^{14}$. E elas compõem boa parte da parca herança que o romancista, segundo Benjamin, receberia melancolicamente do morto. Entretanto, é justamente este instante que falta em Memórias Póstumas de Brás Cubas. Nada passara de um delírio - que Brás Cubas tratará em seu romance como mera curiosidade médica. Nossa hipótese será de que o capítulo "VII - O Delírio" é precisamente aquele em que é destruído todo o poder reconciliador do sentido com a vida que a morte eventualmente possuiria em território romanesco. Neste capítulo há, de fato, um verdadeiro embate entre a musa da reminiscência e outra, a musa da memória épica, à qual estaria ligada desde o início, na epopeia.

\footnotetext{
14 “Aqueles que tiveram experiências de quase morte retornam à vida com uma coleção de memórias ocorridas neste momento. Entre essas memórias, muitos reportaram terem experimentado uma revisão integral da vida" (LONG, 2003, disponível em: http://www.nderf.org/NDERF/Research/purpose lifereview.htm, trad. do autor). Assim diz o site de uma das diversas associações dedicadas a recolher essas experiências de quase morte. Alguns escritores, sobretudo norte-americanos, já disseram terem se baseado neles. Esses relatos, de certo modo, situam-se entre a narrativa romanceada e a curiosidade científica. Entre eles www.nderf.org e http://www.near-death.com.
}

eISSN: $2179-8478$

DOI: $10.17851 / 2179-8478.11 .123-176$ 
O delírio do moribundo Brás Cubas é estimulado pela presença de Virgília. Ela conservara-se diante dele impassível, desconfia até que indiferente, com a iminência de sua morte. Após sugestão de Brás Cubas, levara seu filho junto consigo, para evitar boatos de que fora visitar seu amante. E aproveitara sua presença diante de Cubas para, dissimuladamente, disparar uma palavra "digna e forte" (p.8) contra uma amiga que havia decaído em adultério. Brás Cubas - quem, saberemos, não será pai, não transmitirá a nenhuma outra criatura o legado de sua miséria - queda um pouco estupefato ante o comportamento irresoluto de Virgília, à quem interessa mais transmitir seu legado ao filho que, propriamente, perder-se nas reminiscências de um amor em vias de esvair. De modo que a desfaçatez e indiferença da cena - longe de protagonizar um espetáculo dramalhão de dois amantes que se despedem - irá levá-lo não aos píncaros belos da memória mas à dura indagação: "perguntava a mim mesmo o que diriam de nós os gaviões, se Buffon tivesse nascido gavião...” (p.8)

Com essa imagem - um naturalista convertido em pássaro - é introduzido o delírio, que é logo introduzido por uma série de imagens que de algum modo delimitam os confins do tempo do moderno. Vê-se logo Brás Cubas convertido em uma espécie de barbeiro chinês cujo trabalho seria pago não com dinheiro mas com "beliscões e confeitos: caprichos de mandarim"(p.9). Logo após, sente o corpo transubstanciado na Suma Teológica de São Tomás de Aquino:

impressa num volume, e encadernada em marroquim, com fechos de prata e estampas; ideia esta que me deu ao corpo a mais completa imobilidade; e ainda agora me lembra que, sendo as minhas mãos os fechos do livro, e cruzando-as eu sobre o ventre, alguém as descruzava (Virgília decerto), porque a atitude lhe dava a imagem de um defunto. (p.9)

Deve-se procurar compreender a razão dessa transubstanciação. Trata-se, talvez, de uma referencia implícita à noção de livro da vida, abordada por São Tomás no livro supracitado. São Tomás, a partir de Santo Agostinho, dirá que "o livro da vida não é o

eISSN: $2179-8478$

DOI: $10.17851 / 2179-8478.11 .123-176$ 
mesmo que a predestinação (...) o livro da vida é 'uma certa força divina que fará voltar à memória de cada um suas obras boas ou más.' (...) Se o livro da vida fosse a predestinação, haveria um livro da morte e um livro da vida" (AQUINO, 2001, p.470, grifo do autor). O livro da vida teria a ver com o conhecimento de Deus através do qual se "retém firmemente os que predestinou para a vida eterna" (p.470); sendo portanto livro da vida tanto "o conhecimento da vida gloriosa" (p.471) quanto o "conhecimento da vida da natureza" (p.471). No livro da vida comportam-se inscritos os eleitos para a vida; e o conhecimento dessa predestinação reconhece que "o fim que ultrapassa a natureza é a vida gloriosa. Portanto, o livro da vida se refere propriamente à vida de glória” (p.472, grifo do autor). Por fim, ninguém pode ser verdadeiramente apagado do livro da vida, ainda que isso possa acontecer segundo a opinião dos homens. Não será de nosso interesse aprofundar a concepção de livro da vida de São Tomás; mas de notar que ela em muito reverbera aquilo que Benjamin chamara de ponto de indiferenciação entre musa da reminiscência e musa da memória épica na epopeia. Com efeito, o pássaro naturalista o levara até São Tomás de Aquino, para quem haveria uma mesma tríade interligada na composição do livro da vida: o conhecimento de Deus, perpetuador da reminiscência; a vida gloriosa, cuja predestinação ultrapassa a natureza; e a necessidade de que se intervenha, para além da opinião dos homens, o conhecimento divino e perpetuador, que será inscrito na página. Além disso, há a curiosa insinuação de que, caso o livro da vida fosse o mesmo que predestinação, teriam de haver dois livros, um da vida, outro da morte. Não seria o romance aquele que celebraria, chegada a última página, o sentido definitivo da vida, portanto, celebraria um intuição da predestinação? Em todo caso, que Brás Cubas tenha se convertido, em última instância, em um garboso exemplar da Suma Teológica revela, em muito, a natureza do embate interior ao capítulo.

Brás Cubas volta à forma humana e se vê subitamente nos flancos de um hipopótamo falante. Irá leva-lo numa viagem vertiginosa até à origem dos séculos. Cubas segue a viagem de olhos fechados. Quer saber se a origem "valia alguma coisa mais ou

eISSN: $2179-8478$

DOI: $10.17851 / 2179-8478.11 .123-176$ 
menos do que a consumação dos mesmos séculos: reflexões de cérebro enfermo" (ASSIS, 2008, P.8) A sensação de frio aumenta; abarcam um local de pura neve; a jornada parece-lhe agora:

enfadonha e extravagante, o frio incômodo, a condução violenta, e o resultado impalpável. E depois - cogitações do enfermo - dado que chegássemos ao fim indicado, não era impossível que os séculos, irritados com lhes devassarem a origem, me esmagassem entre as unhas, que deviam ser tão seculares como eles. (p.9)

Alcançam, enfim, uma planície de pura brancura onde, talvez, despontassem aqui ou acolá "uma ou outra planta, enorme, brutesca, meneando ao vento as suas largas folhas. $\mathrm{O}$ silêncio daquela região era igual ao do sepulcro: dissera-se que a vida das coisas ficara estúpida diante do homem.” (p.10).

Vê despontar do nada uma figura imensa, selvática, de mulher, com os olhos rutilantes como o sol, e tudo nela escapando da compreensão do olhar humano; perguntalhe como se chama: "Chama-me Natureza ou Pandora; sou tua mãe e tua inimiga (...) Não te assustes, disse ela, minha inimizade não mata; é sobretudo pela vida que se afirma. Vives, não quero outro flagelo" (p.10).

Alçado pelos cabelos pela Natureza, fita-lhe o rosto e vê:

Nada mais quieto; nenhuma contorção violenta, nenhuma expressão de ódio ou ferocidade; a feição única, geral, completa, era a da impassibilidade egoísta, a da eterna surdez, a da vontade imóvel. Raivas, se as tinha, ficavam encerradas no coração. Ao mesmo tempo, nesse rosto de expressão glacial, havia um ar de juventude, mescla de força e viço, diante do qual me sentia eu o mais débil e decrépito dos seres. (p.10)

Entretanto, recusa-lhe o título de Natureza, que deveria ser apenas mãe, jamais inimiga. Combate-lhe chamando-a de concepção de alienado: uma fábula. Discutem; Brás Cubas quer saber por que he chamam de Pandora - responde-lhe que é porque traz na bolsa os bens e os males, o maior de todos, a esperança; não é apenas a vida, mas também a morte; ela vem anunciar: "tu estás prestes a devolver-me o que te emprestei. Grande

eISSN: $2179-8478$

DOI: $10.17851 / 2179-8478.11 .123-176$ 
lascivo, espera-te a voluptuosidade do nada." (p.11) Desesperado, Brás Cubas clama por viver, ao que ela lhe responde:

Conheces de sobejo tudo o que eu te deparei menos torpe ou menos aflitivo: o alvor do dia, a melancolia da tarde, a quietação da noite, os aspectos da Terra, o sono, enfim, o maior benefício das minhas mãos. Que mais queres tu, sublime idiota? (p.10, grifo do autor)

A Natureza conclui: o egoísmo, a conservação, eis o estatuto universal. A cadência de morte que marca o compasso da vida. Mostra-lhe o passar dos séculos, todos eles, um a um, vertiginosamente:

\footnotetext{
Imagina tu, leitor, uma redução dos séculos, e um desfilar de todos eles, as raças todas, todas as paixões, o tumulto dos Impérios, a guerra dos apetites e dos ódios, a destruição recíproca dos seres e das coisas. Tal era o espetáculo, acerbo e curioso espetáculo. A história do homem e da Terra tinha assim uma intensidade que lhe não podiam dar nem a imaginação nem a ciência, porque a ciência é mais lenta e a imaginação mais vaga, enquanto que o que eu ali via era a condensação viva de todos os tempos. (p.12, grifo do autor)
}

Cubas vê, assim, a glória decair em miséria; o amor multiplicar a miséria; a miséria agravando a debilidade; intervindo assim a cobiça, a cólera, a inveja, a ambição, a fome, a vaidade, a melancolia, a riqueza, o amor: todos animando o homem tal qual um chocalho até destruí-lo, estafado pela aventura, em mero farrapo. Como o verme... "Eram as formas várias de um mal, que ora mordia a víscera, ora mordia o pensamento, e passeava eternamente as suas vestes de arlequim, em derredor da espécie humana.” (p.11) E dói, com a indiferença de um sono sem sonhos; ou com prazer, dor bastarda. Tudo porque o homem, flagelado e rebelde diante da fatalidade das coisas, cisma de ansiar pela ilusão de felicidade - "uma figura nebulosa e esquiva, feita de retalhos, um retalho de impalpável, outro de improvável, outro de invisível, cosidos todos a ponto precário, com a agulha da imaginação" (p.12)

Brás Cubas diverte-se com o espetáculo como um descompassado idiota; e já lhe apetece a ideia de ser digerido. Acelera-se, desse modo, o transcorrer dos séculos; atinge

eISSN: $2179-8478$

DOI: $10.17851 / 2179-8478.11 .123-176$ 
o seu; mas já está enfarado e distraído; a monotonia é deglutida pela velocidade; dada a rapidez da marcha, um século equivalendo ao relâmpago, já não consegue ver o derradeiro; tudo retoma suas formas originais, o hipopótamo sendo, em verdade, seu gato Sultão com uma bola de papel...

eISSN: $2179-8478$

DOI: $10.17851 / 2179-8478.11 .123-176$ 


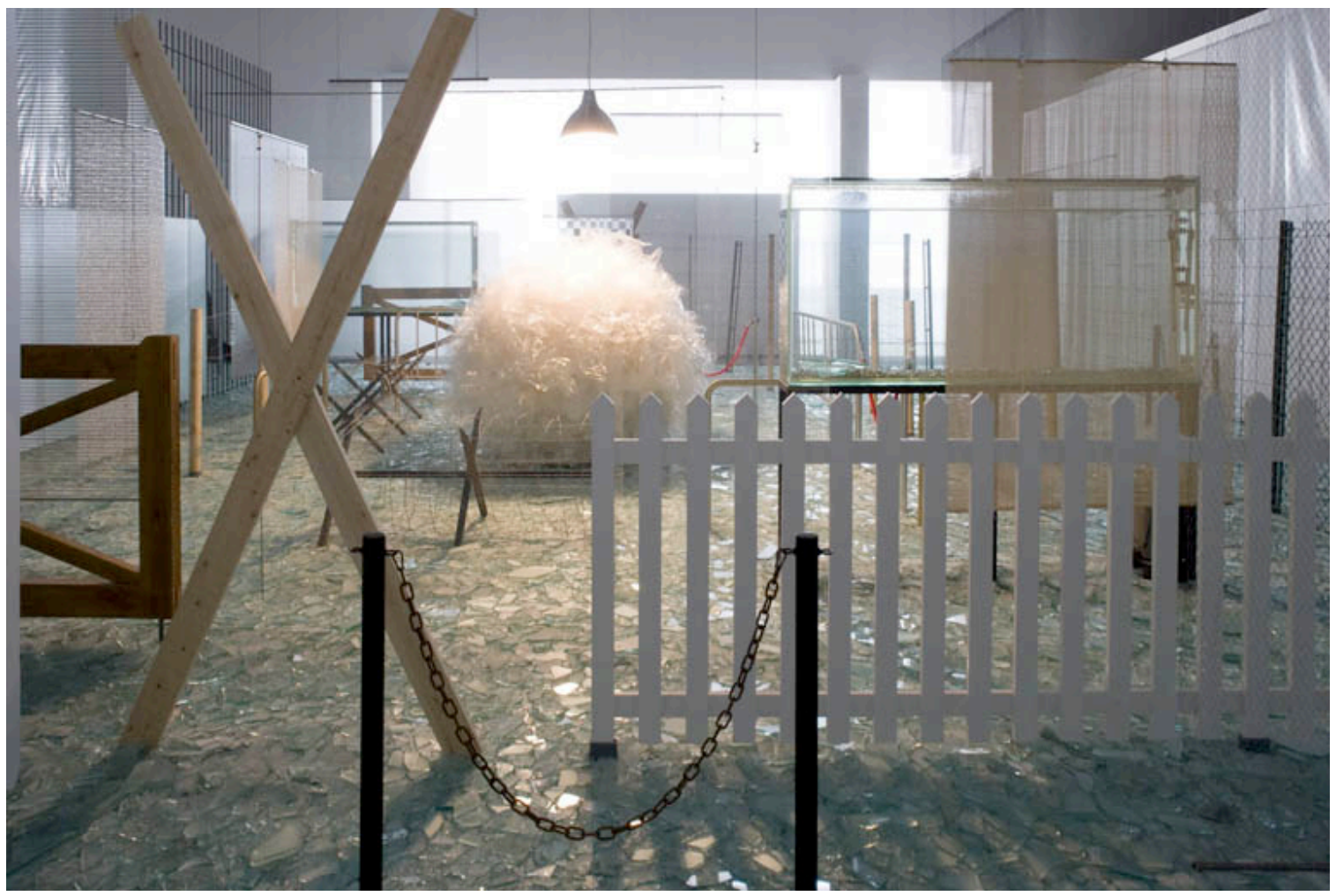

Através, de Cildo Meireles, 1989

Dessarte, a imagem da vida, tal qual se fizera, assim, no delírio:

Ao passo que a vida tinha assim uma regularidade de calendário, fazia-se a história e a civilização, e o homem, nu e desarmado, armava-se e vestia-se, construía o tugúrio e o palácio, a rude aldeia e Tebas de cem portas, criava a

eISSN: $2179-8478$

DOI: $10.17851 / 2179-8478.11 .123-176$ 
ciência, que perscruta, e a arte que enleva, fazia-se orador, mecânico, filósofo, corria a face do globo, descia ao ventre da Terra, subia à esfera das nuvens, colaborando assim na obra misteriosa, com que entretinha a necessidade da vida e a melancolia do desamparo. (p.12, grifo do autor)

Cotejado com o capítulo a partir do ensaio de Benjamin, compreendemos que o saber que a Natureza ou Pandora convoca é, justamente, aquele confiado ao narrador através da musa da memória épica. O narrador - íntimo do dia, da tarde, da noite e do sono; consciencioso da cadência da morte que marca a continuidade da vida (entre elas, a humana); o marinheiro e o camponês, correndo o globo, arando o ventre da Terra, alçando-se, ao seu modo, às nuvens através das escadas da fábula - é o colaborador anônimo da obra misteriosa da natureza. Cose os fios do viver com precisão artesã; entrelaça-o à vida, protege-o do desamparo; na distensão máxima do sono e do tédio, enfrenta a melancolia - orador, mecânico, filósofo: nu e desarmado, o narrador.

Pássaro convertido em naturalista, parte à procura do verdadeiro caráter épico da vida: a face dissolvente, anônima, do homem animado pela cadência de morte. À luz do olhar do gavião naturalista, a parca soma reminiscente do romancista não passa de uma excessiva atenção lasciva e sublimemente idiota lançada à tudo aquilo que é aflitivo, torpe, miseravelmente individual e que, portanto, só pode desconhecer a morte e ignorar o longo enxurro da vida. Luta vã contra a monotonia, o tédio - a ânsia de glória, a sede de nomeada, a voluptuosidade do nada, tudo isto servindo apenas para reforçar a contínua antecipação do mais profundo trauma individual: a morte. Hipocondríacos, restam inertes e delirantes perante a intensidade descomunal da natureza, com sua face impassível, seus olhos rutilantes de sol - a mesma intensidade que trespassa e desconfigura a face do moribundo ${ }^{15}$. Assistem, passivamente, o gato sultão brincar com bolas de papel.

Em Memórias Póstumas de Brás Cubas, não há mais um sentido a ser revelado no fim: a intensidade da memória épica corroera, justamente, o sistema que fundamenta

\footnotetext{
${ }^{15}$ Relembremos a primeira imagem da face, abjeta e incompreensível, de Marcela, da qual despontava qualquer coisa vivaz no olhar; também, a concentração de luz no olhar do pai de Brás Cubas; e, por fím, a estupefaciência de Virgília ante o falecido. Ao repetir "morto, morto!", Virgília esbate-se contra o que é subitamente inapreensível e tautológico daquela morte; e almeja reconciliar o sentido com a vida.
}

eISSN: 2179-8478

DOI: $10.17851 / 2179-8478.11 .123-176$ 
tal revelação. Privara o romance de sua força: a morte como síntese do sentido da vida, perpetuado através do fim do romance. As reminiscências perdem a correspondência última com o sentido e passam a corresponder, tão somente, às sensações que repercutem difusamente. A intensidade da musa da memória épica trespassa o canto da musa da reminiscência, fazendo-o divagar, gaguejar fragmentos narrativos, balbuciar garatujas e diacríticos ásperos - a linguagem no limite do sem-sentido sensorial, tal qual se apresenta aos cansados e enfermos, estafados e lazarentos. Menos que emplasto, o único exemplar que temos em mãos é o sepulcro das reminiscências selado pela força da história natural a qual somente o narrador poderia sibilar. Em Memórias, longe de retrocederem a um estágio anterior de indiferenciação, as musas aniquilam uma à outra suas respectivas ilusões de felicidade - uma, privada da glória da nomeada; a outra, privada da sua intimidade com a Terra e o cotidiano, doravante confinada ao espaço do delírio, da sandice. No interior do livro, as reminiscências apodrecem; convertidas numa espécie de lazarento corpo sem órgãos, roem-nos as reminiscências enquanto as lemos. E, em seu derradeiro canto vermicular indiferente, insinuam: do que lembraremos nós, chegada a hora?

\section{BIBLIOGRAFIA}

AQUINO, São Tomás. Suma Teológica - Teologia, Deus, Trindade. Vol 1; Parte 1. São Paulo: Edições Loyola. 2001

ASSIS, Machado de. Memórias Póstumas de Brás Cubas. Ministério da Educação, 2008. Disponível em: <http://machado.mec.gov.br/images/stories/pdf/romance/marm05.pdf> Acesso em: 19 mai. 2016

BENJAMIN, Walter. O narrador: Considerações sobre a Obra de Nikolai Leskov in: Magia e Técnica, Arte e Política. Trad. Sérgio Paulo Rouanet. São Paulo: Editora Brasiliense. 2012.

BENJAMIN, Walter. Obras Escolhidas II: Rua de Mão Única. São Paulo: Editora Brasiliense, 1987.

CANDIDO, Antônio. "Esquema Machado de Assis" in: Vários Escritos. São Paulo: Duas Cidades, 2004.

eISSN: $2179-8478$

DOI: $10.17851 / 2179-8478.11 .123-176$ 
FOUCAULT, Michel. A Palavra e as Coisas - Uma Arqueologia das Ciências Humanas. São Paulo: Martins Fontes, 2000.

PIGNATARI, Décio. "Rabiscos sem Intenção Alfabética" in: Semiótica e literatura. Coria, SP: Ateliê Editorial, 2004.

SCHWARZ, Roberto. Um Mestre na Periferia do Capitalismo. São Paulo: Editora 34. 2000

VERÍSSIMO, José. História da Literatura Brasileira. Rio de Janeiro: Fundação Biblioteca Nacional. $2002 . \quad$ Disponível em: $<$ http://www.dominiopublico.gov.br/download/texto/bn000116.pdf $>$ Acesso em: 19 mai. 2016 